\title{
2020 DeVelopments in Indiana Evidentiary Practice
}

\author{
COLIN E. FLORA*
}

This survey covers developments in all aspects of Indiana's evidence law between October 1, 2019 and September 30, 2020. As has been long-standing practice, ${ }^{1}$ the format of this survey tracks developments in the same order as the Indiana Rules of Evidence and then covers additional analysis of common-law and statutory practices that fall outside the enumerated provisions of the Indiana Rules of Evidence.

\section{GENERAL PROVISIONS: RULES 101 THROUGH 106}

\section{A. Rule 101: To What Do the Rules Apply}

The applicability and scope of the Indiana Rules of Evidence are established by Rule $101 .^{2}$ As a general matter, the "rules apply in all proceedings in the courts of the State of Indiana" except where specifically made inapplicable. ${ }^{3}$ A commonly recognized area in which the evidence rules yield is that of small claims proceedings, wherein only rules of privilege and prohibitions on use of offers to compromise apply. ${ }^{4}$ There are, however, many more common circumstances in which the rules do not apply, due either to the forum in which the proceedings are heard or the specific stage of proceedings. ${ }^{5}$

Several instances reminding that the specific forum was not one in which the Indiana Rules of Evidence governed arose during the survey period. As Indiana's two federal districts observed, Indiana evidence rules are generally without effect in federal courts. ${ }^{6}$ Similarly, the rules do not strictly apply in most administrative

* Associate Attorney, Pavlack Law, LLC in Indianapolis, Indiana; J.D. 2011, cum laude, Indiana University Robert H. McKinney School of Law; B.A. 2008, with high distinction, Indiana University South Bend. The author also manages the Hoosier Litigation Blog, which focuses on legal developments affecting Indiana practitioners.

1. See, e.g., Edward F. Harney, Jr. \& Jennifer Markavitch, 1995 Survey of Indiana Evidence Law, 29 IND. L. REV. 887 (1996).

2. See IND. R. EvID. 101(a) \& (b).

3. See IND. R. EVID. 101(b) \& (d).

4. IND. R. SM. CL. 8(a); IND. R. Evid. 101(d)(2); M.R. v. B.C., 120 N.E.3d 220, 225 (Ind. Ct. App. 2019). Notably, "[t]he rules and laws with respect to privileges apply at all stages of all actions, cases, and proceedings.” IND. R. EVID. 101(c).

5. See InD. R. Evid. 101(d)(2).

6. Leftridge v. Speedway LLC, No. 2:18-CV-66-JEM, 2019 U.S. Dist. LEXIS 188940, at *2 (N.D. Ind. Oct. 31, 2019); Miller v. Tate \& Kirlin Assocs., Inc., No. 1:19-cv-01353-JRS-DLP, 2020 U.S. Dist. LEXIS 37239, at*7-8 (S.D. Ind. Mar. 4, 2020). If, however, a rule is deemed substantive and not merely procedural, then it may carry into federal court as a substantive aspect of Indiana law. See, e.g., Burton v. Riverboat Inn Corp., No. 4:12-cv-40-WGH-RLY, 2013 U.S. Dist. LEXIS 166709, at*7-10 (S.D. Ind. Nov. 22, 2013) (determining that Indiana Evidence Rule 413 is substantive and may apply in federal court). 
proceedings. ${ }^{7}$ Accordingly, a challenge to findings by the Indiana Athletic Trainers Board as being "based on hearsay, unqualified witness testimony, or unsupported by admissible evidence" proved unsuccessful. ${ }^{8}$

One published decision also addressed a common example of the rules not applying at a specific stage of proceedings, despite the forum - the Howard Superior Court's criminal docket - being one in which the rules would otherwise apply. ${ }^{9}$ In that case, the matter presented to the trial court in the posture of a probation revocation hearing. ${ }^{10}$ But Rule 101(d)(2) exempts probation proceedings from the reach of the rules other than those applying to privilege. ${ }^{11}$ "This flexibility is "necessary to permit the court to exercise its inherent power to enforce obedience to its lawful orders." 12 Under that framework, "[a] trial court has broad discretion in ruling on the admissibility of the evidence at a probation revocation hearing ...."13

\section{B. Rule 103: Preserving Evidentiary Rulings for Appeal}

There are two types of evidentiary problems that each may be properly preserved for review on appeal. ${ }^{14}$ The first is the error in admitting evidence, which must be preserved by a contemporaneous objection accompanied by an explanation of "the specific ground [for the objection], unless it was apparent from the context." 15 The other is in the exclusion of evidence, which must be preserved through an offer of proof, whereby the objecting "party informs the court of [the excluded evidence's substance], unless the substance was apparent from the context." "The purpose of an offer of proof is to convey the point of the [excluded evidence] and provide the trial judge the opportunity to reconsider the evidentiary ruling." ${ }^{17}$ The offer also serves to make the excluded evidence

7. IND. CODE $\S 4-21.5-3-25$ (b) (2021) ("The administrative law judge shall regulate the course of the proceedings in conformity with any prehearing order and in an informal manner without recourse to the technical, common law rules of evidence applicable to civil actions in the courts.").

8. Melton v. Ind. Athletic Trainers Bd., 156 N.E.3d 633, 664-65 (Ind. Ct. App. 2020), reh'g denied (Nov. 6, 2020), trans. denied, 166 N.E.3d 912 (Ind. 2021).

9. Terpstra v. State, 138 N.E.3d 278, 287-88 (Ind. Ct. App. 2019), trans. denied, 143 N.E.3d 965 (Ind. 2020).

10. Id. at $283-84$.

11. IND. R. EvID. 101(d)(2).

12. Terpstra, 138 N.E.3d at 287 (quoting Cox v. State, 706 N.E.2d 547, 550 (Ind. 1999)).

13. Id.

14. If error is not preserved under the provisions of Rule 103(a), then it may only be reviewed for "fundamental error affecting a substantial right" under Rule 103(e). IND. R. EvID. 103(e); Henderson v. Henderson, 139 N.E.3d 227, 236 (Ind. Ct. App. 2019).

15. Ind. R. Evid. 103(a)(1)(B); Flowers v. State, 154 N.E.3d 854, 868 (Ind. Ct. App. 2020).

16. IND. R. EVID. 103(a)(2).

17. Woods v. State, 892 N.E.2d 637, 642 (Ind. 2008) (internal citation omitted); see also Wahl v. State, 148 N.E.3d 1071, 1080 (Ind. Ct. App.), trans. denied, 152 N.E.3d 595 (Ind. 2020). 
available for inclusion in the appellate record, facilitating review of the ruling. ${ }^{18}$ The survey period provided insight into both facets of error preservation.

As a general rule, the failure to timely and adequately object constitutes a waiver of the right to challenge the evidentiary submission. ${ }^{19}$ As a result, a party that does not object to exhibits in a trial court, waives such an objection on appeal. ${ }^{20}$ But waiver of the ability to challenge evidence at the appellate level is not the only possible problem arising from an untimely objection. In the context of summary judgment proceedings, in which Indiana Trial Rule 56 provides a harsh and rigid response deadline, ${ }^{21}$ an attempt to challenge the evidentiary record - specifically, a motion to withdraw admissions - made after the deadline to respond to summary judgment was deemed untimely. ${ }^{22}$ In opting to expand the Trial Rule 56 caselaw to evidentiary challenges, the appellate panel cautioned that to do otherwise "would enable litigants to circumvent our "firmly entrenched' Rule 56 timeframes." ${ }^{23}$ Instead, "[a]n objection to the designated evidence is a response to the designated evidence. Thus, . . . an objection to designated evidence must be included in a timely response and is subject to the same time limitations as any other response to designated evidence under Trial Rule 56." ${ }^{24}$

Although an objection must be timely, it must also be sufficient to adequately inform the court of the basis for the objection. ${ }^{25}$ But what happens when an objecting counsel or litigant is not able to fully articulate the basis for the objection due not to a failing of the objector but owing to the trial court not affording a chance to explain the objection? That was precisely an issue in Caesar v. State. ${ }^{26}$ Avoiding the manifestly unjust result of depriving appellate review

18. Woods, 892 N.E.2d at 642; see also Hill v. State, 137 N.E.3d 926, 939 (Ind. Ct. App. 2019), trans. denied, 143 N.E.3d 949 (Ind. 2020) ("While beneficial to the trial court and the parties, offers of proof 'are invaluable to reviewing courts." (quoting Bedolla v. State, 123 N.E.3d 661, 667 (Ind. 2019))). Offers of proof should not be confused with the procedure of supplementing the clerk's record under Indiana Appellate Rule 31, which applies only where "no Transcript of all or part of the evidence is available.” IND. R. APP. P. 31; see generally Cook v. Beeman, 150 N.E.3d 643, 646 (Ind. Ct. App. 2020).

19. First Chi. Ins. Co. v. Collins, 141 N.E.3d 54, 63 n.7 (Ind. Ct. App. 2020).

20. $I d$.

21. See IND. T.R. 56; Borsuk v. Town of St. John, 820 N.E.2d 118, 123 n.5 (Ind. 2005) (citing Desai v. Croy, 805 N.E.2d 844, 848-49 (Ind. Ct. App. 2004)) (Trial Rule 56(I) does not allow any leeway for trial courts to accept late filings in response to motions for summary judgment); Desai, 805 N.E.2d at 851 (Baker, J., dissenting) (describing the majority view of T.R. 56(I) as "rigid"); Nightingale Home Healthcare, Inc. v. Oliva, No. 29A02-0902-CV-117, 2009 Ind. App. Unpub. LEXIS 1037, at*12 (Ind. Ct. App. Aug. 13, 2009) (describing approach as "harsh"), trans. denied, 929 N.E.2d 784 (Ind. 2010).

22. State ex rel. Hill v. Jones-Elliott, 141 N.E.3d 1264, 1268 (Ind. Ct. App. 2020).

23. Id. (quoting Mitchell v. 10th \& The Bypass, LLC, 3 N.E.3d 967, 973 (Ind. 2014)).

24. $I d$.

25. IND. R. EvID. 103(a)(1).

26. Caesar v. State, 139 N.E.3d 289 (Ind. Ct. App.), trans. denied, 145 N.E.3d 112 (Ind. 
where the objector was twice interrupted by the court and each objection overruled without "opportunity to elaborate," the Indiana Court of Appeals rebuffed the State's contention that objections to secondary evidence had not been adequately preserved. ${ }^{27}$

Similar to Caesar, Hill v. State also presented an instance in which the trial court was alleged to have cut short the procedural safeguards for preserving an evidentiary challenge - there, an attempt to conduct an offer of proof. ${ }^{28}$ "Generally, a party has a right to make an offer of proof and it is reversible error for a trial court to deny a party the opportunity to explain the substance, relevance, and admissibility of excluded evidence with an offer of proof." ${ }^{29}$ But a court need not allow the exact mechanism of proof that a party seeks in order to satisfy its obligation to allow for an offer of proof. In Hill, the defendant sought to conduct an offer of proof by having an excluded witness testify to what he would have said had he been permitted to testify to the jury. ${ }^{30}$ The trial court, having heard what the substance of the anticipated testimony would have been by explanation of the defendant's counsel, did not allow the witness to take the stand for the purpose of conducting an offer of proof. ${ }^{31}$ Because the attorney had already gone "into significant detail regarding what [the witness] would have said during his testimony[, $\mathrm{t}$ ] he trial court was not required to hear [his] live testimony to re-state what [the] attorney [already] stated." ${ }^{32}$ That conclusion is in line with the Indiana Supreme Court's ruling in Bedolla v. State, ${ }^{33}$ which was covered in the last survey. ${ }^{34}$

\section{Rule 104: Preliminary Questions About Admissibility of Evidence}

Rule 104 entrusts the duty of resolving preliminary questions as to admissibility with the trial court. ${ }^{35}$ Because a trial court is better suited to observe and weigh credibility judgments than an appellate court, the trial court's conclusions are not second guessed on appeal. ${ }^{36}$ While the trial court is afforded broad discretion, there is a practice that has now drawn slight rebuke from the

2020).

27. Id. at 291 n.2.

28. Hill v. State, 137 N.E.3d 926, 938-40 (Ind. Ct. App. 2019), trans. denied, 143 N.E.3d 949 (Ind. 2020).

29. Id. at 939 (citations and quotation marks omitted).

30. Id. at $939-40$.

31. Id. at 940 .

32. Id.

33. Bedolla v. State, 123 N.E.3d 661, 667 (Ind. 2019) ("Of course, as part of its duty to impartially control a proceeding, the "court may exercise reasonable discretion in determining the timing and extent' of an offer of proof." (citations omitted)).

34. Colin E. Flora, 2019 Developments in Indiana Evidentiary Practice, 53 IND. L. REV. 895, 897-98 (2021) [hereinafter 2019 Survey].

35. IND. R. EvID. 104(a).

36. Id. 
Indiana Court of Appeals in the last two survey periods: the practice of accepting evidentiary submissions while taking ruling on admissibility under advisement. ${ }^{37}$

Covered in the last survey, ${ }^{38}$ Rose v. State cautioned against such a practice, advising that "the better practice would be to make a ruling on the admissibility of evidence during the hearing so the parties have adequate notice as to what evidence the court will use to make its decision." 39 The same approach was taken by the trial court in Terpstra v. State. ${ }^{40}$ On appeal, the panel did not find the practice to be a basis for reversal, at least in the absence of a jury. ${ }^{41}$ Nevertheless, as in Rose, the panel expressed concerns with such practice, writing:

Although we do not encourage trial courts to conduct probation revocation proceedings in this manner, we conclude that to hold that a trial court under these circumstances must always immediately rule on evidentiary objections would be to unnecessarily limit the discretion of the trial court and to ignore the increased flexibility of probation revocation proceedings. ${ }^{42}$

With two entirely different panels expressing reservations over taking evidentiary rulings under advisement, ${ }^{43}$ where possible, it is a practice best avoided completely. That point is further emphasized by then-Chief Judge Nancy Vaidik's dissent in Terpstra, which, although based largely in the trial court's failure to issue evidentiary rulings in its ultimate findings, highlights the problem of depriving parties of contemporaneous rulings on evidentiary submissions. ${ }^{44}$

\section{JUDICIAL NOTICE: RULE 201}

A foundational premise of Indiana's judicial system is that "[j]udges are never presumed to be ignorant of the laws of their own country, from whatever

37. See Terpstra v. State, 138 N.E.3d 278, 288 (Ind. Ct. App. 2019), trans. denied, 143 N.E.3d 965 (Ind. 2020); Rose v. State, 120 N.E.3d 262, 265 n.2 (Ind. Ct. App.), trans. denied, 127 N.E.3d 232 (Ind. 2019).

38. 2019 Survey, supra note 34 , at 898-99.

39. Rose, 120 N.E.3d at 265 n.2.

40. Terpstra, 138 N.E. $3 \mathrm{~d}$ at 288.

41. Id. ("Terpstra seemingly argues on appeal that the trial court had a duty to rule immediately on the admissibility of the challenged evidence, citing Stephenson v. State, 205 Ind. 141, 163, 179 N.E. 633, 661 (Ind. 1932), a case which we find to be unpersuasive because it involved a jury trial, not the more flexible probation revocation and bench trial at issue here, and it did not hold that a trial court may not take evidentiary rulings under advisement. Terpstra presents us with no authority for his apparent proposition that a trial court conducting a probation revocation hearing may not take evidentiary rulings under advisement.").

42. Id.

43. The panel in Rose was comprised of Judges May, Baker, and Robb. The panel in Terpstra was comprised of Judge Riley, now-Chief Judge Bradford, and then-Chief Judge Vaidik.

44. Terpstra, 138 N.E.2d at 290 (Vaidik, C.J., dissenting) ("A judge is required to rule on objections - full stop. Parties are entitled to know the basis of a judge's decision.”). 
source they may have originated" 45 and that "courts will not pretend to be more ignorant than the rest of mankind." ${ }^{46}$ The procedural mechanisms that ensure judicial common sense prevails over rigid formalism is judicial notice as embodied both in Indiana Evidence Rule 201 and Indiana's adoption of the Uniform Judicial Notice of Foreign Law Act. ${ }^{47}$ There are two categories of judicial notice: notice of facts ${ }^{48}$ and notice of law. ${ }^{49}$ The survey period shed further light into both categories.

With regard to facts that may be judicially noticed, there are some facts that a court may notice for the truth and substance of the fact itself, ${ }^{50}$ and other facts which courts may do no more than take notice of their existence. ${ }^{51}$ Rule 201(a)(1) allows judicial notice of facts that are either "not subject to reasonable dispute because [they are] generally known within the trial court's territorial jurisdiction, or [ ] can be accurately and readily determined from sources whose accuracy cannot reasonably be questioned." ${ }^{52}$ The survey period provided three examples of facts that are appropriately noticed under Rule 201(a)(1). Brown v. State found it was proper for a court to take judicial notice that signatures on two letters that had been sent to the court by a criminal defendant were the signature of the defendant and could be used by a jury to compare with a disputed signature. ${ }^{53}$ Notably, the letters were admissible even though the defendant was represented by counsel when they were mailed to the court. ${ }^{54}$ In a child-custody matter, it was similarly found appropriate for the trial court to take "judicial notice of previous hearings, and its own file, to note Mother's dismissive and hostile attitude toward co-parenting, while also taking note of Father's general attitude of cooperation." 55

The third example is considerably more noteworthy. In a footnote to Williams

45. Henthorn v. Doe, 1 Blackf. 157, 164 (Ind. 1822).

46. State v. Louisville \& Nashville R.R. Co., 96 N.E. 340, 344 (Ind. 1911).

47. IND. R. Evid. 201; IND. CoDE $\S \S 34-38-4-1$ to -7 (2021).

48. IND. R. EVID. 201(a).

49. IND. R. EvID. 201(b); IND. CODE $\S \S 34-38-4-1$ to -7.

50. IND. R. EVID. 201(a)(1).

51. IND. R. EVID. 201(a)(2). Whether the fact, once judicially noticed, is deemed conclusively established or is subject to being rejected by a jury, depends on whether the action is civil or criminal. IND. R. EvID. 201(f) ("In a civil case, the court must instruct the jury to accept the noticed fact as conclusive. In a criminal case, the court must instruct the jury that it may or may not accept the noticed fact as conclusive.").

52. IND. R. Evid. 201(a)(1).

53. Brown v. State, 146 N.E.3d 1031, 1037-38 (Ind. Ct. App.), trans. denied, 150 N.E.3d 1020 (Ind. 2020).

54. Id. at 1038. The import of allowing the signatures to be considered despite the defendant being represented by counsel is that the Indiana Supreme Court, in Owen v. State, approved of judicial notice that the pleadings by a pro se litigant had been signed by the litigant, thereby creating "a rebuttable presumption ... requir[ing] the defendant to come forward with any evidence to dispute the presumption." Id. (quoting Owen v. State, 396 N.E.2d 376, 381 (Ind. 1979)).

55. McDaniel v. McDaniel, 150 N.E.3d 282, 290. (Ind. Ct. App.), trans. denied, 160 N.E.3d 512 (Ind. 2020). 
v. Indiana Department of Correction, the Indiana Court of Appeals concluded that "judicial notice of the Mayo Clinic's website of general facts relating to diseases, their symptoms, and their common medications" fell within the acceptable bounds of Rule 201(a)(1)(B). ${ }^{56}$ While it is often said that Indiana's "[S] upreme [C]ourt does not decide important questions of law in footnotes," it would appear the same is not necessarily true of Indiana's intermediate court. ${ }^{58}$ Readers may recall that the propriety of applying judicial notice to postings on the Mayo Clinic's website once resulted in a spirited debate between Seventh Circuit Judges David Hamilton and Richard Posner, ${ }^{59}$ but seems to have been more easily accepted by the Indiana Court of Appeals.

One of the more interesting provisions under Rule 201 is found at both subdivisions $(\mathrm{a})(2)(\mathrm{C})$ and $(\mathrm{b})(5) \cdot{ }^{60}$ Contrary to modern practice, "[h]istorically, judicial notice of court records was typically circumscribed." ${ }^{\prime 1}$ It is easy to forget that, "[f]or years, [Evidence] Rule 201 did not permit a trial court to take judicial notice of court records, even if they were its own records in another case previously before the court on a related subject with related parties." ${ }^{162}$ It was not until a 2009 amendment to Indiana Evidence Rule 201 that Indiana courts became

56. Williams v. Ind. Dep’t of Corr., 142 N.E.3d 986, 991 n.2 (Ind. Ct. App. 2020), reh'g granted.

57. Jones v. State, 807 N.E.2d 58, 67 (Ind. Ct. App. 2004); see also Allstate Indem. Co. v. Brown, 696 N.E.2d 92, 95 (Ind. Ct. App. 1998); Molden v. State, 750 N.E.2d 448, 451 (Ind. Ct. App. 2001); Townsend v. State, 860 N.E.2d 1268, 1274 (Ind. Ct. App. 2007); T.B. v. Review Bd. of the Ind. Dep't of Workforce Dev., 980 N.E.2d 341, 346 (Ind. Ct. App. 2012).

58. One commentator has noted, however, that even the Indiana Supreme "Court does decide important issues in footnotes. Statements of [the Indiana] Court of Appeals to the contrary therefore appear to be inaccurate." William A. Ramsey, Taking Note of Footnotes: The Precedential Value of Footnotes in Judicial Opinions, 54 Res GeSTæ, Sept. 2010, at 10, 16.

59. Rowe v. Gibson, 798 F.3d 622 (7th Cir. 2015). For analysis and commentary, see generally M. Cristina Martin, “Googling” Your Way to Justice: How Judge Posner Was (Almost) Correct in His Use of Internet Research in Rowe v. Gibson, 11 SEventh Circuit Rev. 1 (2015); Amy Huang, Note, E-Judge: Independent Judicial Research and the Pro Se Prisoner, 62 WAYNE L. REv. 249 (2017); see also Gregory W. Segal, Note, Clashing Standards in the Courtroom: Judicial Notice of Scientific Facts, 51 Colum. J.L. \& Soc. ProbS. 523, 527, 544-45 (2018); Lissa Griffin, Judging During Crises: Can Judges Protect the Facts?, 50 LoY. U. CHI. L.J. 857, 873-74 (2019).

60. IND. R. EvID. 201(a)(2)(C) ("The court may judicially notice... (2) the existence of ... (C) records of a court of this state.”); IND. R. EvID. 201(b)(5) (“A court may judicially notice a law, which includes... (5) records of a court of this state....").

61. Zephyr Teachout, Facts in Exile: Corruption and Abstraction in Citizens United v. Federal Election Commission, 42 LoY. U. CHI. L.J. 295, 302 (2011).

62. Johnson v. State, 140 N.E.3d 854, 859 (Ind. Ct. App. 2019) (second alteration in original; quotation marks and citation omitted), trans. granted and opinion vacated, 143 N.E.3d 945 (Ind.), decision reached on remand, No. 20A-CR-1489, 2020 Ind. App. Unpub. LEXIS 1502 (Ct. App. Dec. 29, 2020). 
permitted "to take judicial notice of records of a court of this state." ${ }^{63}$ Numerous instances of judicial notice of court records were deemed appropriate during the survey period, including: notice of chronological case summaries in related cases filed by the same plaintiff ${ }^{64}$; notice of a previously filed and dismissed criminal action in a subsequent action arising from the same allegations ${ }^{65}$; that a criminal defendant, who is also a licensed attorney, had been reprimanded for a prior conviction $^{66}$; that a part-time deputy prosecutor had filed appearances in criminal cases as well as child-support matters ${ }^{67}$; the transcript of testimony provided in a prior sentencing hearing within the same criminal case ${ }^{68}$; and records of an administrative proceeding relating to a party's licensure that had been filed in support of a separate action for judicial review. ${ }^{69}$

The survey period showed, however, that judicial notice is not a tool of unlimited scope. While Rule 201 now allows courts to take judicial notice of court records, it is confined to "records of a court of this state." "70 Although not a point that has been heavily litigated, it is a point the Indiana Court of Appeals observed in rejecting a request to "take judicial notice of the proceedings in [a] federal case." ${ }^{\prime 1}$ As the court succinctly stated, "Because [the litigant] cites no authority for the proposition that state courts may take judicial notice of federal proceedings, we deny her request." ${ }^{\prime 2}$ This aspect of Indiana's Rule 201 rests in direct contrast to federal practice, which permits courts to take judicial notice of "proceeding[s] in other courts, both within and outside of the federal judicial system, if the proceedings have a direct relation to matters at issue." ${ }^{.73}$

63. Id.; accord Wahl v. State, 148 N.E.3d 1071, 1087 (Ind. Ct. App.), trans. denied, 152 N.E.3d 595 (Ind. 2020).

64. Kindred v. Ind. Dep't of Child Servs., 136 N.E.3d 284, 287 n.1 (Ind. Ct. App. 2019), trans. denied, 145 N.E.3d 115 (Ind. 2020).

65. Moore v. State, 143 N.E.3d 334, 338 n.1 (Ind. Ct. App.), trans. denied, 149 N.E.3d 605 (Ind. 2020).

66. Knight v. State, 155 N.E.3d 1242, 1245 n.2 (Ind. Ct. App. 2020).

67. State v. Herrmann, 151 N.E.3d 1256, 1257 n.1 (Ind. Ct. App.), trans. denied, 157 N.E.3d 529 (Ind. 2020).

68. Wahl v. State, 148 N.E.3d 1071, 1087 (Ind. Ct. App.), trans. denied, 152 N.E.3d 595 (Ind. 2020).

69. Abbott v. Individual Support Home Health Agency, Inc., 148 N.E.3d 1091, 1095 n.2 (Ind. Ct. App.), trans. denied, 157 N.E.3d 525 (Ind. 2020).

70. IND. R. EvID. 201(a)(2)(C) \& (b)(5).

71. Turkette v. State, 151 N.E.3d 782, 785 n.2 (Ind. Ct. App.), trans. denied, 157 N.E.3d 528 (Ind. 2020).

72. Id.

73. Opoka v. Immigration \& Naturalization Serv., 94 F.3d 392, 394 (7th Cir. 1996) (citation and quotation marks omitted); accord 520 S. Mich. Ave. Assocs., Ltd. v. Shannon, 549 F.3d 1119, 1137 n.14 (7th Cir. 2008); see, e.g., Webber v. Butner, No. 1:16-cv-01169-TWP-DML, 2017 U.S. Dist. LEXIS 209062, at *6-9 (S.D. Ind. Dec. 20, 2017). 


\section{RELEVANCY \& ITS LIMITS: RULES 401 THROUGH 413}

\section{A. Rules 401 \& 402: What Is and Is Not Relevant}

Relevant evidence is generally admissible and irrelevant evidence is inadmissible. ${ }^{74}$ "Relevant evidence is defined as evidence 'having any tendency to make the existence of any fact that is of consequence to the determination of the action more probable or less probable than it would be without the evidence." "'75 Moreover, the fact must be "of consequence in determining the action." " The survey period yielded surprisingly few decisions directly addressing the issue of relevance under Rule 401.

In Smith v. State, the Indiana Court of Appeals, in affirming the exclusion of a sexual-assault victim's post-assault sexual history, found that the victim's sexual history was not relevant to prove that someone else caused the victim's vaginal injury because "the State did not introduce evidence of the injury." 77 The only other decision of note was Poore v. Indianapolis Public Schools, also from the court of appeals, which ruled that the testimony of a parent who had a similar experience with the defendant one year after the plaintiffs' experience, was not relevant to the plaintiffs' claims "sounding in negligence, breach of contract, and deceptive practices" arising from representations made to them by the defendant because the testimony could only reflect on what that parent was told, not on what the plaintiffs had been told or their experiences with the defendant. ${ }^{78}$

\section{B. Rule 403: Excluding Relevant Evidence for Prejudice, Confusion, or Other Reasons}

"Although evidence must be relevant to be admissible, not all relevant evidence is admissible." "'A9 "As a general matter, [under Rule 403, ]any relevant evidence may be excluded 'if its probative value is substantially outweighed by a danger of one or more of the following: unfair prejudice, confusing the issues, misleading the jury, undue delay, or needlessly presenting cumulative evidence." " "The balancing of the probative value against the danger of unfair prejudice must be determined with reference to the issue to be proved by the evidence." ${ }^{" 81}$ Importantly, it is not sufficient to trigger exclusion under Rule 403 that "evidence is prejudicial in some sense"; rather, the question is "whether the

74. IND. R. EvID. 402.

75. Poore v. Indianapolis Pub. Sch., 155 N.E.3d 643, 649 (Ind. Ct. App. 2020) (quoting IND. R. EvID. 401), summarily aff'd in relevant part on trans., 164 N.E.3d 130 (Ind. 2021).

76. IND. R. EvID. 401(b).

77. Smith v. State, 140 N.E.3d 363, 371 (Ind. Ct. App.), trans. denied, 145 N.E.3d 119 (Ind. 2020).

78. Poore, 155 N.E.3d at $648-50$.

79. Id. at 649 (citation and quotation marks omitted).

80. Friend v. State, 134 N.E.3d 441, 448 (Ind. Ct. App. 2019) (quoting IND. R. EvID. 403), trans. denied, 141 N.E.3d 25 (Ind.), cert. denied, 141 S. Ct. 162 (2020).

81. Ward v. State, 138 N.E.3d 268, 273 (Ind. Ct. App. 2019) (citation omitted). 
evidence is unfairly prejudicial.""s2 "In evaluating whether this evidence is unfairly prejudicial and should have been excluded, 'courts will look for the dangers that the jury will (1) substantially overestimate the value of the evidence or (2) that the evidence will arouse or inflame the passions or sympathies of the jury." ${ }^{83}$

Likely the most significant opinion of the survey period to analyze Rule 403 is McAnalley v. State. ${ }^{84}$ The issue presented was whether "the trial court abused its discretion by instructing the jury on the specific nature of [the defendant]'s prior felony, and admitting evidence of the specific prior felony, when [the defendant] had offered to stipulate to his status as a person who could not lawfully possess a firearm." ${ }^{\prime 55}$ The defendant's position was well supported by the Indiana Supreme Court's Hardister v. State opinion, in which the court found: "Where status as a felon is an element of the crime charged and the defendant stipulates to his status as a felon, admission into evidence of the full record of a defendant's prior felony conviction is an abuse of discretion under Indiana Rule of Evidence 403." ${ }^{\prime 66}$ Further supportive is the Supreme Court of the United States' opinion in Old Chief $v$. United States.$^{87}$ Ultimately, the court concluded that the admission "would have been reversible error," "[b]ut for the overwhelming evidence against" the defendant. ${ }^{88}$

The majority of the appellate panel advised "that better practice would be to follow the holdings in the United States Supreme Court opinion in Old Chief, and the Indiana Supreme Court opinion in Russell [v. State]," so as to bifurcate the trial with the determination of whether the defendant was a violent felon reserved for a second phase of the proceedings. ${ }^{89}$ On that point, however, the majority and now-Chief Judge Cale Bradford disagreed. ${ }^{90}$ Judge Bradford was not of the opinion "that bifurcation is a better or necessary practice in cases such as this." In his esteem, a better solution would be "for the trial court to craft instructions and accept stipulations that minimize the potential for prejudice by stating 'previously convicted of a felony enumerated under Indiana Code section 35-47$4-5$ ' instead of explicitly naming the prior felony conviction or referring to it as a serious violent felony."${ }^{, 92}$

82. Id. (emphasis added) (citation omitted).

83. Id. at 274 (quoting Duvall v. State, 978 N.E.2d 417, 428 (Ind. Ct. App. 2012)).

84. McAnalley v. State, 134 N.E.3d 488, 507-12 (Ind. Ct. App. 2019), trans. denied, 141 N.E.3d 33 (Ind. 2020).

85. Id. at 507.

86. Id. at 508 (quoting Hardister v. State, 849 N.E.2d 563, 577 (Ind. 2006)).

87. Id. at 509-12 (discussing Old Chief v. United States, 519 U.S. 172 (1997)).

88. Id. at 511.

89. Id. at 512 (discussing Russell v. State, 997 N.E.2d 351, 352 (Ind. 2013)).

90. Id. at 512-13 (Bradford, J., concurring in result).

91. Id. at 512 .

92. Id. at 513. Judge Bradford also disagreed that the specific stipulation by the defendant was sufficient because the defendant, "through his counsel, was willing to agree to a stipulation being read to the jury that [he] is 'a person who cannot have a gun lawfully.' This stipulation, 
Several other decisions from the Indiana Court of Appeals also added guidance to the application of Rule 403. In Friend v. State, no error was found in the exclusion of 137 text messages and testimony by an expert witness to support the proposition that the alleged victim, an adopted daughter of the defendant, suffered from Reactive Attachment Disorder ("RAD"), ${ }^{93}$ allegedly making her more likely to fabricate her claims because the alleged victim had not been diagnosed with RAD, many of the text messages actually depicted a positive relationship with the alleged victim, and it was otherwise not unreasonable to conclude that 137 messages and the lengthy testimony of the expert constituted cumulative evidence. ${ }^{94}$

In another decision, Ward v. State, the court of appeals upheld the admission of a criminal defendant's singing of a rap-styled song that "describes the story of a murder in which the murderer approaches the door of the victims, enters, and shoots the victims in the head and body." would almost certainly have not been sufficient for admission, that the song was authored by the defendant, uploaded approximately two months after the charged murder, and provided an "accurate description of the murder scene," made it "highly probative of [the defendant]'s participation in the crimes." ${ }^{96}$ Notably, the trial court provided a limiting instruction to the jury that:

This item is being introduced for a limited purpose. It is not being admitted and you may not consider it in any way to determine that [the defendant] is a bad person or [the defendant], in terms of the lyrical content, there are going, there are going to be slang terms, and other things that you may find that you may disagree with or unacceptable. ${ }^{97}$

"Accordingly, the trial court instructed the jurors that regardless of their response to the lyrical content of the song, they could not convict [ ] based on his 'artistic license,' or as a sign that [he] lauded the murders." 98

In Echeverria v. State, the court of appeals rejected two Rule 403 evidentiary challenges. ${ }^{99}$ The first challenge was to the testifying officer's description of "the

however, is not sufficient to establish that [he] is a serious violent felon, which is what the statute requires. There are plenty of Hoosiers who cannot lawfully have a gun, e.g., certain individuals with a mental illness or a domestic-battery conviction, who are not serious violent felons." Id. (citations omitted).

93. RAD "is a psychological condition that results from a lack of an intimate bond between parent and child during infancy. RAD is often diagnosed in adopted children due to their sometimes unstable upbringing; it is characterized by meanness, physical aggression, lying, cruelty to animals, and an apparent lack of empathy." Friend v. State, 134 N.E.3d 441, 444 (Ind. Ct. App. 2019), trans. denied, 141 N.E.3d 25 (Ind.), cert. denied, 141 S. Ct. 162 (2020).

94. Id. at 448 .

95. Ward v. State, 138 N.E.3d 268, 272-73 (Ind. Ct. App. 2019).

96. Id. at 274 .

97. Id. (citation omitted).

98. Id. (citation omitted).

99. Echeverria v. State, 146 N.E.3d 943, 947-50 (Ind. Ct. App.), trans. denied, 150 N.E.3d 
role of the IMPD 'Flex' team" as "a proactive unit tasked with reducing crime, going after targeted violent offenders involved with firearms, narcotics." ${ }^{100}$ The argument was that the "description of the 'Flex' team painted [the defendant] as a violent felon who traffics in firearms and narcotics." ${ }^{101}$ The court rejected the challenge because the officer's description "did not characterize [the defendant] as a violent criminal. Rather, as the trial court pointed out, [the officer was] 'simply answering the question of what he does for a living and the purpose of the flex team." 102 While "prejudice may arise in a jury trial when a defendant is identified and repeatedly referred to as a "serious violent felon," that was "the only testimony where [the officer] made any remark about how the 'Flex' team specializes in targeting violent offenders." 103 The minor prejudice occasioned by the testimony was not sufficient to overcome the "high probative value in the testimony." 104

The second Rule 403 challenge proved no more fruitful. ${ }^{105}$ During the execution of a search warrant that resulted in the arrest of the defendant, hundreds of grams of methamphetamine, more than fifty grams of heroin, other drugrelated materials, and four firearms were discovered. ${ }^{106}$ Relying on Brown v. State, the defendant urged that the four firearms were not relevant, as "possession or use of a firearm does not comprise any elements of the crimes with which [the defendant] was charged." 107 The appellate panel distinguished Brown because the present defendant's charges included

dealing in methamphetamine and in a narcotic drug, and [the Indiana] Supreme Court has previously held that the presence or possession of a firearm near or by a criminal defendant, along with a significant amount of drugs and paraphernalia, can support a conclusion that the defendant had the intent to deliver. ${ }^{108}$

That precedent made the firearms probative of the specific crimes charged. ${ }^{109}$

The court of appeals found no error in excluding the post-assault sexual history of a victim of rape under Rule 403, which the defendant, in Smith v. State, contended would have shown a motive for the victim to fabricate the allegation

1020 (Ind. 2020).

100. Id. at 947 .

101. Id.

102. Id. at 948 .

103. Id. (emphasis omitted) (citation omitted).

104. Id. ("It was important for the jurors to understand [the officer]'s position and the work that the 'Flex' team does in these types of situations.").

105. Id. at 949-50.

106. Id. at 946 .

107. Id. at 949 (discussing Brown v. State, 747 N.E.2d 66, 68 (Ind. Ct. App. 2001)).

108. Id. at 949-50 (citing J.L.H. v. State, 642 N.E.2d 1368, 1370 (Ind. 1994)).

109. Id. at 950. The appellate court did not, however, appear to engage in the balancing of the prejudice against the probative value of the firearms, instead satisfied for admission having rebuffed the wholesale rejection that would have been occasioned by pure reliance on Brown. 
"because she was ashamed she had consensual sex with [the defendant] and was afraid that [the person she was dating] would find out what she had done." ${ }^{110}$ In so deciding, the appellate court found that "[e]ven if the evidence was probative of [the] defense, its probative value was greatly outweighed by the increased chance that [the victim]'s sexuality would be put on trial and become the focus of the defense, which is precisely what Rule 412 is meant to prohibit." 111

Ivory v. State, decided under a fundamental-error standard of review, indicated that the probative value of DNA-test results based on relatively new STRmix software was sufficient to outweigh any confusion or undue prejudice from admission of such evidence, at least where the proponent "explained for the jury the basic steps of the DNA profiling process and how the STRmix program works within that process." 112 Warren $v$. State reminded, in passing, that before evidence of a third-party motive is admissible, "the defendant must show some connection between the third party and the crime[s]." ${ }^{\prime 13}$ And, in Vigus v. Dinner Theater of Indiana, a civil-tort action, the court of appeals affirmed the exclusion of post-accident communications between a business's owners to seek a variance to reduce the height of a riser on which the plaintiff was injured because the finding by the trial court that "the relevance, if any, of the owners" communications to seek a variance after [the plaintiff]'s fall would be substantially outweighed by the danger of suggesting to the jury that the owners knew at the time of [the] fall of the alleged danger posed by the riser," was within the permissible bounds of the trial court's discretion. ${ }^{114}$

\section{Rule 404: Character Evidence, Crimes, Wrongs or Other Acts}

Rule 404 generally prohibits the use of evidence of a person's character, crime, wrong, or other act to show "that on a particular occasion the person acted in accordance with the character or trait." 15 "The purpose of the rule is to protect against the forbidden inference that the defendant acted badly in the past, and that the defendant's present, charged actions conform with those past bad acts." "116 The rule affords certain exceptions to its general prohibition. ${ }^{117}$ For example, Indiana,

110. Smith v. State, 140 N.E.3d 363, 372-73 (Ind. Ct. App.), trans. denied, 145 N.E.3d 119 (Ind. 2020).

111. Id. at 372 .

112. Ivory v. State, 141 N.E.3d 1273, 1281-82 (Ind. Ct. App.), trans. denied, 153 N.E.3d 1101 (Ind. 2020).

113. Warren v. State, 146 N.E.3d 972, 979 (Ind. Ct. App.) (quoting Pelley v. State, 901 N.E.2d 494, 505 (Ind. 2009)), trans. denied, 150 N.E.3d 1025 (Ind.), cert. denied, 141 S. Ct. 858 (2020).

114. Vigus v. Dinner Theater of Ind., L.P., 153 N.E.3d 1150, 1161-62 (Ind. Ct. App. 2020), trans. denied, 165 N.E.3d 79 (2021).

115. IND. R. Evid. 404(a)(1) \& (b)(1); Echeverria v. State, 146 N.E.3d 943, 947 (Ind. Ct. App.), trans. denied, 150 N.E.3d 1020 (Ind. 2020).

116. Vanryn v. State, 155 N.E.3d 1254, 1264 (Ind. Ct. App. 2020).

117. See Ind. R. Evid. 404(a)(2), (a)(3) \& (b)(2). Rule 406 also constitutes an exception to Rule 404's general prohibition on the use of character evidence. Yeoman v. Ikea U.S. W., Inc., No. 
like most jurisdictions, allows the introduction of character evidence against a criminal defendant if the defendant “"open[s] the door' to such evidence either by introducing character witnesses of their own or by attacking the character of the victim," 118 or, a homicide "victim's character for peacefulness to rebut evidence that the victim was the first aggressor." 119 Most commonly, it is the rule's second subdivision that garners the most focus of appellate courts, as it was during this survey period.

Because it is intended to prohibit the forbidden inference- "that prior wrongful conduct suggests present guilt"- "[t]he effect of Rule 404(b) is that evidence is excluded only when it is introduced to prove the forbidden inference of demonstrating the defendant's propensity to commit the charged crime." ${ }^{20}$ As recognized in Hall v. State, admission of evidence that may otherwise be excluded by Rule 404(b) will not be found as erroneous where the party challenging admission invited the error. ${ }^{121}$ Further, even if error was not invited, a timely objection must be rendered or any subsequent challenge will face the uphill struggle of showing fundamental error in the admission. ${ }^{122}$ A similar conclusion was echoed in Norton v. State, which demonstrated that where trial counsel fails to object to testimony running afoul of Rule 404(b) and contemporaneously request an admonishment to the jury, an appellate court may not subsequently find that an admonition ought to have been given. ${ }^{123}$

Also arising under a fundamental-error standard of review, Mise v. State addressed the use of prior misconduct with minors in the prosecution of molestation of those same minors. ${ }^{124}$ Rule 404(b)(2) permits evidence otherwise excluded under Rule 404(b)(1)

to prove "motive, opportunity, intent, preparation, plan, knowledge, identity, absence of mistake, or lack of accident." ... When assessing the admissibility of evidence under Evidence Rule 404(b), the trial court must: (1) determine whether the evidence of other crimes, wrongs, or acts is relevant to a matter at issue other than the defendant's propensity to commit the charged act; and (2) balance the probative value of the evidence against its prejudicial effect pursuant to Evidence Rule 403. ${ }^{125}$

The gravamen of the defendant's argument was "that, because he was

$11 \mathrm{cv} 701$ WQH (BGS), 2014 U.S. Dist. LEXIS 22156, at*8-9 (S.D. Cal. Feb. 20, 2014).

118. Komakhuk v. State, 460 P.3d 797, 800 (Alaska Ct. App. 2020) (citing inter alia IND. R. EVID. 404(a)(2)(A) \& (B)).

119. Id. at 802 (emphasis omitted) (citing inter alia IND. R. EvID. 404(a)(2)(C)).

120. Hall v. State, 137 N.E.3d 279, 284 (Ind. Ct. App. 2019) (citation omitted).

121. Id.

122. Id. at 285 .

123. Norton v. State, 137 N.E.3d 974, 982-83 (Ind. Ct. App. 2019), trans. denied, 145 N.E.3d 107 (Ind. 2020).

124. Mise v. State, 142 N.E.3d 1079, 1086 (Ind. Ct. App.), trans. denied, 150 N.E.3d 1018 (Ind. 2020).

125. Id. at 1086 (quoting IND. R. EvID. 404(b)(2)). 
charged with only one count of child molesting for each girl, it was fundamental error for the trial court to allow [each] to testify to multiple instances." ${ }^{126}$ The Indiana Court of Appeals rejected that argument, finding "Evidence Rule 404(b) does not [ ] bar evidence of repeated incidents of sex offenses that occurred within the charged timeframe where such evidence is 'direct evidence' of guilt of the charged offenses and not evidence of other crimes or wrongs."127 Moreover,

evidence of a defendant's ... "grooming" - or "the process of cultivating trust with a victim and gradually introducing sexual behaviors until reaching the point where it is possible to perpetrate a sex crime against the victim" is relevant and establishes a valid basis for the admission of evidence under Rule 404(b). ${ }^{128}$

Although deemed waived, the court of appeals also addressed the defendant's late-raised argument that he was not provided "reasonable notice-before or during trial — of the general nature of the evidence that [the State] intended to offer" in contravention of the notice procedures of Rule 404(b)(2). ${ }^{129}$ The court found sufficient notice because "the incidents were discussed during [the defendant]'s police interview, were apparently contained on the video of [one victim]'s forensic interview that the State provided to [the defendant] pursuant to a discovery request, and were discussed during opening statements at trial." 130

In Echeverria v. State, the question was whether Rule 404(b) necessitated exclusion of "roughly twenty-eight pages of ledgers of drug transactions" found as part of the execution of a search warrant. ${ }^{131}$ First, the court had to determine whether the prosecution provided adequate advance notice. ${ }^{132}$ Fearing that the ledgers would be used at trial, the defendant "filed a written request for copies of the ledgers pursuant to Indiana Evidence Rule 404(b)" in November 2018. ${ }^{133}$ "The State did not respond to [the] request and ultimately did not provide copies of the ledgers until March 15, 2019-three days before trial." "134 "[D]etermining whether the State's notice was reasonable requires an examination of whether the purpose of the notice provision was achieved in light of the circumstances of a particular case." 135 Because the defendant knew of the high likelihood that the ledgers would be used, based on the defendant being specifically questioned by police regarding the ledgers on the night of the search and that she had

126. $I d$.

127. Id.

128. Id. at 1087 (citations omitted).

129. Id. at $1087 \mathrm{n} .4$.

130. Id.

131. Echeverria v. State, 146 N.E.3d 943, 946, 948-49 (Ind. Ct. App.), trans. denied, 150 N.E.3d 1020 (Ind. 2020).

132. Id. at 946 .

133. Id.

134. Id. at $946-47$.

135. Id. at 948 (emphasis in original) (citation omitted). 
specifically requested copies, and received copies at least three days before trial, the court found reasonable notice in accordance with Rule 404(b)(2). ${ }^{136}$

The court then turned to whether the evidence would be unduly prejudicial. ${ }^{137}$ "Conced[ing] that [the defendant] raise[d] strong arguments about how the ledgers might impugn her character and paint her as a repeat narcotics dealer," the court still found the probative value sufficiently strong to warrant admission. ${ }^{138}$ In the court's esteem, "[t]he ledgers ha[d] substantial probative value for purposes of establishing intent, identity, or even preparation, and while they might have some prejudicial effect, it [did] not outweigh their probative value." 139

Vanryn $v$. State highlighted a crucial distinction between Indiana's application of Rule 404(b) contrary to federal counterparts. ${ }^{140}$ Relying on Pirnat $v$. State, the defendant argued that a video posted to Facebook in which the mother of the child he was accused of battering stated that he had hit the child's head was not sufficiently close in time to be relevant to the charged offense. ${ }^{141}$ The Indiana Court of Appeals rejected reliance on Pirnat because it had "applied the Seventh Circuit's four-part test for the admissibility of 404(b) evidence, which included a factor that 'the other evidence must be similar enough and close enough in time to be relevant to the matter in issue." "142 The Indiana Supreme Court's Hicks v. State opinion, however, rejected "the requirement that the prior bad act must be similar and close in time to the charged conduct in order to be relevant." "143 Instead, Indiana adds "the significance of the similarity or remoteness of evidence" as a consideration for the broad discretion of trial courts in assessing whether evidence is admissible under Rule 404(b) ${ }^{144}$ While "[s]ome proffered evidence may be irrelevant because it is too remote[,] an event occurring in the past can be critical. Therefore, admissibility hinges on relevance, not a litmus test based on an isolated factor - remoteness, similarity, or anything else - that may bear on relevance." ${ }^{145}$ To the degree timeliness merited consideration, the court

further note[d] that the State established the timeliness of the Facebook video in two respects. First, [the m] other stated in her Facebook post that it was the last video that she had taken of [the child] the night before he died. In addition, the video showed the scar on [the child]'s lip, which was caused by [his] fall in the shower and which was still healing just

136. $I d$.

137. Id. at 949 .

138. Id.

139. Id.

140. Vanryn v. State, 155 N.E.3d 1254, 1264-65 (Ind. Ct. App. 2020).

141. Id. at 1260-61, 1265 (citing Pirnat v. State, 612 N.E.2d 153, 155 (Ind. Ct. App. 1993), abrogated by Hicks v. State, 690 N.E.2d 215 (Ind. 1997)).

142. Id. at 1265 (quoting Pirnat, 612 N.E.2d at 155) (alteration in original).

143. Id. (citing Hicks, 690 N.E.2d at 219).

144. Id. (quoting Hicks, 690 N.E.2d at 220).

145. Id. (alterations in original) (quoting Hicks, 690 N.E.2d at 220) (quotation marks omitted). 
one month before [his] death. ${ }^{146}$

The rule was also considered in the context of a child in need of services ("CHINS") proceeding. ${ }^{147}$ Because Indiana Code section 31-34-1-1 makes a parent's character "a material issue in [CHINS] proceeding[s]," the probable cause affidavit from a father's nearly decade-old criminal conviction, even if "admitted solely 'to establish a pattern of ongoing domestic violence and physical abuse towards [the m]other," is admissible at the first CHINS proceeding pertaining to the child..$^{148}$

\section{Rule 405: Character Evidence in CHINS Proceedings}

Once character evidence is deemed admissible under Rule 404, then the analysis turns to Rule 405 to establish the methods for proving character. ${ }^{149}$ Under Rule 405(b), “[w]hen a person's character or character trait is an essential element of a charge, claim, or defense, the character or trait may also be proved by relevant specific instances of the person's conduct." ${ }^{150}$ In CHINS ${ }^{151}$ matters, "a parent's character is a material issue in the proceeding." 152 As such, it may generally be said that "Indiana Rule of Evidence 405(b) allows admission of specific instances of a parent's character because a parent's past, present, and future ability to provide sufficient care for his or her child forms the basis for a CHINS adjudication and a parent's character is an integral part of assessing that ability." 153 There is, however, one qualifier: "past acts by parents in CHINS proceedings can be relevant, but [ ] this practice [is limited] to 'new CHINS filings involving the same parents and children." 154 Applying that view of Rule 405(b), the Indiana Court of Appeals affirmed admission of a father's prior criminal conviction because the matter was "the first CHINS proceeding pertaining to the [c]hild." 155

\section{E. Rule 408: Compromise Offers \& Negotiations}

The sanctity of settlement communications is held in the utmost esteem, with even the lax procedures embodied by the Indiana Small Claims Rules enshrining

146. Id

147. In re L.T., 145 N.E.3d 864, 870 (Ind. Ct. App. 2020).

148. Id.; see also IND. CODE $§ 31-34-1-1$ (2021).

149. Johnson v. State, 671 N.E.2d 1203, 1207 (Ind. Ct. App. 1996).

150. IND. R. EvID. 405(b).

151. CHINS stands for "a Child in Need of Services" in accordance with Indiana Code section 31-34. In re L.T., 145 N.E.3d at 866; see IND. CoDE §§ 31-34-1 to -25.

152. In re L.T., 145 N.E.3d at 870 (citing In re J.L.V., 667 N.E.2d 186, 190 (Ind. Ct. App. 1996)).

153. Id. (citation and quotation marks omitted).

154. Id. (quoting In re Eq.W., 124 N.E.3d 1201, 1211 (Ind. 2019)); see also IND. CODE § 3134-12-5.

155. Id. 
protection from use. ${ }^{156}$ The Indiana Rules of Evidence safeguard compromise offers and negotiations through Rule $408 .{ }^{157}$ Where settlement negotiations result in an agreement, Rule 408 uncomfortably intersects contract law. That is particularly true in the context of family law, in which "mediations have become commonplace" 158 and marital settlement agreements are both governed by the substantive law of contracts and are innately compromises subject to the prohibitions of Rule 408(a). ${ }^{159}$ The intersection between substantive contract law and Rule 408(a) posed a substantial issue for the Indiana Court of Appeals in Berg v. Berg. ${ }^{160}$

The Bergs attended mediation, resulting in a marital settlement agreement that the trial court directly incorporated into its dissolution order. ${ }^{161}$ One day shy of a year later, the former wife moved to set aside the dissolution order by contending that the settlement agreement had erroneously failed to incorporate a stock account valued at $\$ 122,000 .{ }^{162}$ The former husband resisted the motion on the basis that the arguments invited the court to rely on discussions from the mediation that were barred by Rule 408(a). ${ }^{163}$ The trial court agreed with the former wife and awarded her half the value of the account. ${ }^{164}$ She had successfully sought to use the mediation evidence as a basis to avoid the settlement agreement as the product of "fraud, constructive fraud, mutual mistake, misrepresentation, or other misconduct." ${ }^{\prime 65}$ She also relied on the mediation evidence to establish that the former husband had breached a warranty in the agreement. ${ }^{166}$

On appeal, the majority of the appellate panel agreed with most of the former husband's arguments, reversing the trial court as a result. ${ }^{167}$ The majority began by acknowledging that the Indiana Supreme Court's Horner v. Carter opinion established that even though Rule 408(b) permits evidence of settlement

156. IND. R. SM. CL. 8(A) ("The trial shall be informal, with the sole objective of dispensing speedy justice between the parties according to the rules of substantive law, and shall not be bound by the statutory provisions or rules of practice, procedure, pleadings or evidence except provisions relating to privileged communications and offers of compromise.").

157. See InD. R. Evid. 408.

158. Rebecca Berfanger, Courts Offer CHINS Facilitations, IND. LAw. (Jan. 18, 2011), https://www.theindianalawyer.com/articles/25582-courts-offer-chins-facilitations [https://perma.cc/H45X-RC85]; see also InD. R. Alt. Disp. Resol. 2.11(B)(1) ("Mediation shall be regarded as settlement negotiations governed by Indiana Evidence Rule 408.").

159. Berg v. Berg, 151 N.E.3d 321, 325-26 (Ind. Ct. App.), reh'g denied (Sept. 15, 2020), vacated, 170 N.E.3d 224 (Ind. 2021).

160. Id. at 326-28.

161. Id. at 324 .

162. Id.

163. Id. at 325 .

164. Id.

165. Id. at 328.

166. Id. at 329.

167. Id. at 326-31. 
negotiations to be admissible for other purposes, the "exception allows mediation evidence [only] to be used 'in collateral matters unrelated to the dispute that is the subject of the mediation." "168 Using mediation evidence to attempt to avoid the settlement agreement, as the trial court had allowed, amounted to use in a collateral matter barred by Rule $408 .{ }^{169}$

Use of the mediation evidence to show that the former husband had breached the warranty, however, was deemed a permissible use under Rule $408 .{ }^{170}$ As the majority explained,

Under Horner, discussions involved in negotiating and reaching a final settlement agreement are excluded from subsequent disputes unless the dispute involves a distinct collateral matter. Enforcement of the terms of the Settlement Agreement would be such a collateral matter. Thus, the exception in Rule 408 would allow the admission of mediation evidence for the collateral purpose of enforcing the Settlement Agreement. ${ }^{171}$

Nevertheless, the majority found the breach-of-warranty argument unviable because the warranties were mutual-i.e., both persons warranted that "there has been a full disclosure of all their assets"- and the former wife was estopped from rejecting her own representations in the warranty. ${ }^{172}$

In dissent, Judge Terry Crone did not directly reject the majority's general understanding of Rule 408. ${ }^{173}$ Instead, the dissent focused on two issues: (1) that the former husband's appellate arguments were insufficiently cogent so as to constitute waiver of the Rule-408 issue on appeal; and (2) a challenge to how Rule 408 was applied to the specific record presented. ${ }^{174}$ The first issue is of no concern for purposes of this survey. ${ }^{175}$ The second issue, on the other hand, raises an important point: whether "“discussions and communications had in anticipation of mediation' are inadmissible pursuant to Evidence Rule 408."176 The dissent's reading of the record was that notes of the former wife's counsel from mediation were simply cumulative of counsel's notes from prior to mediation, which were also part of the record. ${ }^{177}$

As part of the conclusion that the former husband had waived his Rule 408 arguments on appeal, the dissent observed that the former husband "cite[d] no authority for the proposition." 178 Notably, the dissent did not itself cite authority

168. Id. at 327 (quoting Horner v. Carter, 981 N.E.2d 1210, 1212 (Ind. 2013)).

169. Id. at 328-29.

170. Id. at 329.

171. Id. (citations omitted).

172. Id. at 330-31.

173. Id. at 331-32 (Crone, J., dissenting).

174. Id.

175. For those interested in that issue, compare id. at $326 \mathrm{n} .5$ (majority opinion), with id. at 331-32 (Crone, J., dissenting).

176. Id. at 331-32 (emphasis in original).

177. Id. at 332 .

178. Id. at 331-32. 
to the contrary, instead, appearing to take it as a given that Rule 408 was limited to discussions at mediation. ${ }^{179}$ Federal courts, applying "the substantially similar" Federal Rule of Evidence $408,{ }^{180}$ have developed robust caselaw considering the issue. In 1991, the United States District Court for the District of Maryland determined that "Rule 408 does not apply to internal [settlement-related] memoranda unless communicated to the other side in an attempt at settlement." While that decision supports Judge Crone's dissenting view, it has proven to be an outlier in the caselaw. The apparent majority of courts that have considered the issue reject the conclusion of the District of Maryland, choosing instead to exclude internal memoranda and other documents made in preparation of compromise negotiations, regardless of whether the documents were ever transmitted to an opposing party. ${ }^{182}$

Following the close of the survey period, the Indiana Supreme Court granted transfer and affirmed the trial court, finding "[ $t]$ he trial court incorrectly determined that fraud, constructive fraud, mutual mistake, or misrepresentation had occurred, but . . . didn't abuse its discretion in finding that Husband had breached the warranty clause of the Agreement." 183 The Indiana Supreme Court's opinion will be addressed in next year's survey.

\section{F. Rule 412: Victims'Sexual Behavior or Predisposition}

The Indiana General Assembly has enacted Indiana's Rape Shield Statute. ${ }^{184}$ Rule 412 "embodies" that statute by "recogniz[ing] that 'inquiry into a victim's [other] sexual activity is sufficiently problematic that it should not be permitted to become the focus of the defense." 185 As a result, "[i]n cases involving alleged sexual misconduct, evidence offered to prove that a victim or witness engaged in other sexual behavior or evidence offered to prove a victim's or witness's sexual

179. Id.

180. Id. at 327 n.6 (majority opinion).

181. Blue Circle Atl., v. Falcon Materials, Inc., 760 F. Supp. 516, 522 (D. Md. 1991), aff'd, 960 F.2d 145 (Table), No. 91-2099, 1992 WL 79536 (4th Cir. 1992) (per curiam).

182. See, e.g., Affiliated Mfrs., Inc. v. Aluminum Co. of Am., 56 F.3d 521, 528-30 (3d Cir. 1995); EEOC v. UMB Bank Fin. Corp., 558 F.3d 784, 791 (8th Cir. 2009) ("The spirit of the Rule, as recognized by several circuits and as set forth in the commentary to the Rule, supports the exclusion of certain work product, internal memos, and other materials created specifically for the purpose of conciliation, even if not communicated to the other party."); Cribari v. Allstate Fire \& Cas. Ins. Co., No. 16-cv-02450-NRN, 2019 U.S. Dist. LEXIS 97738, at*17-19 (D. Colo. June 11, 2019); Gucker v. U.S. Steel Corp., No. 13-583, 2016 U.S. Dist. LEXIS 10770, at *3-5 (W.D. Pa. Jan. 29, 2016); Applebaum v. Target Corp., No. 11-cv-15035, 2015 U.S. Dist. LEXIS 190264, at *4-6 (E.D. Mich. Feb. 11, 2015); Xcoal Energy \& Res., LP v. Smith, 635 F. Supp. 2d 453, 454-55 (W.D. Va. 2009); see also Axenics, Inc. v. Turner Constr. Co., 62 A.3d 754, 767-68 (N.H. 2013).

183. Berg v. Berg, 170 N.E.3d 224, 232 (Ind. 2021).

184. IND. CODE $§ 35-37-4-4$ (2021).

185. Smith v. State, 140 N.E.3d 363, 371 (Ind. Ct. App.) (alteration in original) (quoting Williams v. State, 681 N.E.2d 195, 200 (Ind. 1997)), trans. denied, 145 N.E.3d 119 (Ind. 2020). 
predisposition is generally not admissible under" Rule $412 .{ }^{186}$ The rule "prevent[s] the victim of a sexual assault from being placed on trial and to remove impediments to reporting sex crimes." 187 The rule's "prohibition on evidence of the victim's other sexual behavior or predisposition is not[, however,] absolute." ${ }^{\prime 188}$ Three criminal appeals to Indiana's intermediate appellate court shined light on when the general prohibition of Rule 412 may or may not bend.

At the start of the survey period, the court tackled the question of whether a victim's internet search history was admissible under one of Rule 412(b)'s exceptions. ${ }^{189}$ Complicating the analysis was that the eleven-year-old victim was also the daughter of the criminal defendant and shared a tablet from which the search history was pulled. ${ }^{190}$ The defendant, who was charged with engaging in incest with his minor daughter, unsuccessfully sought to enter into evidence that the tablet's search history "included 'sex games,' 'daddy sleeping with daughter,' and "f__ king games." "191

The defendant contended that the evidence should have been introduced "to counter the so-called 'sexual innocence inference' theory." ${ }^{192}$ Under that theory, it is inferred that young children "are ignorant of matters relating to sexual conduct, [such that] a child complainant's ability to describe such conduct may persuade the jury that the charged conduct in fact occurred." 193 In order to rebut that inference, defendants seek to admit evidence to show "that the child acquired sexual experience with someone else before he or she accused the defendant." 194 Indiana has "adopted what has been referred to as the 'compromise approach' to questions involving the sexual innocence inference theory." 195 That approach places "the burden [ ] on the defendant to show that the prior sexual act occurred and that the prior sexual act was sufficiently similar to the present sexual act to give the victim the knowledge to imagine the molestation charge." ${ }^{196}$ The court of appeals affirmed exclusion because the defendant never established that it was the victim who conducted the searches on the tablet. ${ }^{197}$ The court reasoned, because both the defendant and victim shared access to the tablet,

the jury could just as easily have concluded that [the defendant] performed the internet searches, given the fact that the tablet had been

186. Watson v. State, 134 N.E.3d 1038, 1042 (Ind. Ct. App. 2019), trans. denied, 141 N.E.3d 21 (Ind. 2020).

187. Smith, 140 N.E.3d at 370 (citation omitted).

188. Id.; see also IND. R. EvID. 412(b).

189. Watson, 134 N.E.3d at 1041-43.

190. Id. at 1041 .

191. Id.

192. Id. at 1043.

193. Id. (citation omitted).

194. Id. (citation omitted).

195. Id. (citation omitted).

196. Id. (citation and quotation marks omitted).

197. Id. 
shared by both .... The jury could also have determined that even if [the victim] had conducted the searches, they were in response to [the defendant]'s acts of molestations. ${ }^{198}$

At the start of 2020, the court of appeals once more returned to Rule 412 . There, the defendant sought to admit the victim's sexual history to assert that a vaginal injury, documented in the victim's records, was caused by someone other than the defendant. ${ }^{199}$ Although Rule 412(b)(1)(A) permits "evidence of specific instances of a victim's or witness's sexual behavior, if offered to prove that someone other than the defendant was the source of semen, injury, or other physical evidence, ${ }^{200}$ the evidence still needed to be relevant. ${ }^{201}$ Where, as in this instance, the prosecution never introduced evidence of the physical injury, evidence designed to rebut the source of the injury was inadmissible. ${ }^{202}$

The defendant also sought to admit the evidence under Rule 412(b)(1)(C)'s catchall allowing admission where exclusion would violate a constitutional right of the defendant. ${ }^{203}$ "Whether it is rooted directly in the Due Process Clause of the Fourteenth Amendment or the Compulsory Process or Confrontation clauses of the Sixth Amendment, the Constitution guarantees criminal defendants a meaningful opportunity to present a complete defense." ${ }^{\text {204 }}$ The appellate court ruled that there was no such violation because the defendant, whose theory was that the victim contrived the allegations to conceal from another that she had consensually engaged in intercourse with the defendant, was permitted to fully probe the conduct including the victim's potential motivations at trial, ultimately only being "prevented from presenting the jury with evidence of [the victim]'s other sexual behavior which allegedly occurred after the offenses and had nothing to do with the events which formed the bases for the charges against him." ${ }^{205}$

Finally, in June, the court again addressed Rule 412, this time in the context of a grandfather charged with engaging in sexual conduct with his teenage granddaughter resulting in her pregnancy. ${ }^{206}$ The grandfather sought to enter evidence that his son, the victim's father, had been "convicted of sexual misconduct with a minor in 1994."207 The rationale of the defense was that

198. Id. The court of appeals also rejected a challenge to an exclusion under Rule 412(b)(1)(C), which permits "evidence whose exclusion would violate the defendant's constitutional rights" because the witness was presented live at trial, undermining any confrontation clause challenge. Id. at 1044-45; IND. R. EvID. 412(b)(1)(C).

199. Smith v. State, 140 N.E.3d 363, 370-73 (Ind. Ct. App.), trans. denied, 145 N.E.3d 119 (Ind. 2020).

200. IND. R. EvID. 412(b)(1)(A).

201. Smith, 140 N.E.3d at 370-71.

202. Id.

203. Id. at 371-73.

204. Id. at 372 (citation omitted).

205. Id

206. Killian v. State, 149 N.E.3d 1189, 1189-91 (Ind. Ct. App. 2020).

207. Id. at 1189. 
because the father had been convicted of such a crime, two decades in the past, it could be the father, not the grandfather, who had impregnated the victim. ${ }^{208}$ The argument went nowhere as "Rule 412(b)(1)(A) only allows evidence of other sexual behavior that - itself - could have 'produced' some physical evidence that is presented in the case." ${ }^{209}$ Clearly, the father's decades-old conviction was not the specific instance that could have produced the victim's 2017 pregnancy. ${ }^{210}$ The grandfather produced no other evidence that the father ever had intercourse with the victim. ${ }^{211}$ Instead, the court concluded, "He simply wanted the jury to speculate that because [the f]ather engaged in sexual misconduct with a different person in the past, he did so with his daughter over twenty years later. That is not the purpose of Rule 412(b)(1)(A)."212

\section{PRIVILEGES: RULES $501 \& 502$}

Rule 101(c) establishes that " $[\mathrm{t}]$ he rules and laws with respect to privileges apply at all stages of all actions, cases, and proceedings." ${ }^{213}$ Rule 501 generally prohibits privileges "except as provided by constitution, statute, any rules promulgated by the Indiana Supreme Court, or common law." 214 Indiana "generally recognizes that privileges are statutory in nature and that it is within the power of the legislature to create them." ${ }^{215}$ A reason for privileges being primarily statutory in nature is because "[m]ost privileges were unknown at common law." 216 The effect of common law reluctance to recognize privileges means courts tasked with applying statutory privileges must strictly construe such privileges "to limit their application." 217

Likely the most relied upon statutory provision regarding privilege is Indiana Code section 34-46-3-1, which establishes attorney-client privilege, patientphysician privilege, clergymen privilege, and marital-communications privilege. ${ }^{218}$ " $[\mathrm{T}]$ he purpose of th[at] privileges statute is to prevent certain

208. Id. at 1190.

209. Id. at 1191.

210. Id.

211. Id.

212. Id.

213. IND. R. EVID. 101(c).

214. IND. R. EVID. 501(a).

215. State v. Pelley, 828 N.E.2d 915, 918 (Ind. 2005); but see Henry v. Cmty. Healthcare Sys. Cmty. Hosp., 134 N.E.3d 435, 438 n.3 (Ind. Ct. App. 2019) ("We acknowledge the caselaw providing that, in the context of the doctor-patient privilege in our judicial system, the privilege did not exist at common law and is, instead, a statutory creation of the legislature. E.g., Terre Haute Reg'l Hosp., Inc. v. Trueblood, 600 N.E.2d 1358 (Ind. 1992). But we do not believe that the existence of this privilege in the context of our judicial system has any bearing on the historical duty of confidentiality owed by medical providers to their patients.").

216. Pelley, 828 N.E.2d at 918.

217. Id.

218. IND. CODE § 34-46-3-1 (2021). 
statements by a person . . . 'made to' an attorney, physician, or clergyman from being used in evidence against the defendant." ${ }^{219}$ Despite the need to narrowly construe statutory privileges, Indiana courts "place greater value on protecting such statements in such relationships than on their use as evidence."220

\section{A. Clergymen Privilege}

The clergymen privilege applies to both "[c]onfessions or admissions made to a clergyman in the course of discipline enjoined by the clergyman's church" and "[a] confidential communication made to a clergyman in the clergyman's professional character as a spiritual adviser or counselor."221 The Indiana Court of Appeals' opinion in Elliott v. State produced a thorough analysis of both categories of communications to a clergyman following a criminal defendant's pastor testifying that the defendant "admitted to him that he had planted the knife at the scene of the shooting." 222 The pastor visited the defendant on three occasions, while the defendant was held in jail. ${ }^{223}$ "During the second visit, [the defendant] told the pastor that he planted the knife at the scene of the shooting." 224

The court first considered whether the communications fell within the course of discipline. ${ }^{225}$ During his second visit with the criminal defendant, the pastor "delivered . . . a letter containing church discipline because the pastor and the church had discovered that [the defendant]'s claim of self-defense had been called into question." ${ }^{.26}$ It was in response to and upon receipt of the letter, that the defendant told the pastor that he "did not lie except for the knife, [he] planted the knife but everything else" remained the same. ${ }^{227}$ Ultimately, application of the privilege turned on the dogma of the church. Despite the letter appearing to be clearly within the bounds of "course of discipline," "the pastor testified that the Reformed Presbyterian Church does not recognize a formal confession[,] . . . that the church recognizes 'the need for discretion but not confidentiality[,]" and that the church did not require a formal confession "in order to 'get right with God." $" 228$

The court of appeals also rejected reliance on the second category of the privilege. The substance of the first of the three visits to the jail would likely have satisfied the privilege. "At trial, [the pastor] testified that the first time he met

219. Elliott v. State, 152 N.E.3d 27, 34 (Ind. Ct. App.), trans. denied, 157 N.E.3d 531 (Ind. 2020).

220. Id.

221. IND. CODE $\S 34-46-3-1(3)$.

222. Elliott, 152 N.E.3d at 33.

223. Id.

224. Id.

225. Id. at 35-38 (discussing IND. CODE § 34-46-3-1(3)(A)).

226. Id at 37 .

227. Id. at 38 .

228. Id. (citations omitted). 
with [the defendant] at the jail, he did so as his pastor to provide pastoral care."229 But, on the crucial second visit, the pastor was not there to provide pastoral care; instead, he was there to inform the defendant that his "church privileges had been suspended." ${ }^{230}$ The court of appeals found "nothing in th[e] conversation . . . indicat [ing] that [the defendant] expected any confidentiality on the pastor's part or that [he] was seeking spiritual advice or counseling from [the pastor] in [his] professional character." ${ }^{231}$ That conclusion was further buttressed by the pastor's testimony "that confession was not part of the Reformed Presbyterian Church's discipline; the church recognized the need for discretion but not confidentiality; and if a member of the church reported a crime to him, he believed it was his responsibility to report the crime to the authorities." ${ }^{232}$

\section{B. Attorney-Client Privilege}

When federal courts sit in diversity jurisdiction, they must "look to state law in determining the existence and scope of the attorney-client privilege." ${ }^{233}$ Interpreting Indiana's attorney-client privilege, the United States District Court for the Southern District of Indiana produced two important insights. First, the court stood behind its own precedent to conclude that "attorney-client privilege [can] extend to internal documents and communications between employees" because "[i]ndividuals in an organizational structure are permitted to consult with one another about an attorney's legal advice so that all relevant information is known before making a legal decision without waiving the privilege." 234 And, second, a defendant's denial that "it acted in bad faith does not invoke the socalled 'put-in-issue' exception" to attorney-client privilege, which applies when a party places its mental state at issue in asserting a claim or defense that can only be tested by an opposing party by lowering the shield of attorney-client privilege. ${ }^{235}$

\section{Peer-Review Privilege}

A different code section provided the privilege at issue in Bonzani v. Goshen

229. $I d$.

230. Id.

231. Id.

232. Id.

233. Greenbank v. Great Am. Assurance Co., No. 3:18-cv-00239-SEB-MPB, 2019 U.S. Dist. LEXIS 210805, at*15 (S.D. Ind. Dec. 4, 2019) (citation omitted).

234. Id. at *17-18 (quoting Carr v. Fed. Bureau of Prisons, No. 2:14-cv-00001-WTL-MJD, 2017 U.S. Dist. LEXIS 106489, at*3 (S.D. Ind. July 10, 2017)) (internal quotation marks omitted).

235. Id. at *21-22; see also Doherty v. Purdue Props. I, LLC, 153 N.E.3d 228, 238 (Ind. Ct. App. 2020) ("As an illustration of this principle in action, the Indiana Supreme Court has concluded that "when a patient who is a party to a lawsuit places his mental or physical condition in issue, he has done an act which is so incompatible with an invocation of the physician-patient privilege as to that condition that he has impliedly waived the privilege to that extent." (quoting Canfield v. Sandock, 563 N.E.2d 526, 529 (Ind. 1990))), trans. denied, 165 N.E.3d 60 (Ind. 2021). 
Health Systems, the peer-review privilege. ${ }^{236}$ The privilege "provides that determinations of the peer review committee may not be discovered or admitted in a judicial proceeding absent written waiver." ${ }^{237}$ In a failed attempt to invoke immunity for defamation, medical defendants invoked the Indiana Peer Review Privilege of Indiana Code section 34-30-15-9. ${ }^{238}$ The United States District Court for the Northern District of Indiana rejected use of the privilege in such a manner. ${ }^{239}$ In so doing, the court also observed that "the privilege has its limitations. 'Disclosure of the results or consequences of a proceeding (namely, the restrictions placed on a doctor's staff privileges) is not inconsistent with the purpose of the privilege: to encourage candor by the medical personnel on the committee." 240 The district court further called into question whether a report with the National Practitioner Data Bank is even within the scope of the privilege. ${ }^{241}$

\section{Counselor-Client Privilege}

The Indiana Court of Appeals also briefly addressed the counselor-client privilege embodied in Indiana Code section 25-23.6-6-1. ${ }^{242}$ A criminal defendant sought to obtain records of a minor molestation victim's one-on-one sessions with a social worker to support his argument that the victim "was fabricating the molestation allegations." 243 A majority of the appellate panel found that the documents were "plainly . . . privileged and may not be disclosed unless they fall under one of the statutorily-defined exceptions - none of which appl[ied]." ${ }^{244}$

Dissenting in part, Judge Crone would have found that the privilege did not prohibit the defendant from obtaining the documents. ${ }^{245}$ Judge Crone observed that " $[\mathrm{t}] \mathrm{he}$ interest advanced by the counselor-client privilege is substantially similar to that advanced by the victim advocate privilege . . ., namely, to foster 'an atmosphere of confidence and trust in which the patient is willing to make a frank and complete disclosure of facts, emotions, memories, and fears." "246 Importantly, in Judge Crone's esteem, "[u]nlike the victim advocate privilege, [ ] the counselor-client privilege is not absolute; Indiana Code Section 25-23.6-6-1

236. Bonzani v. Goshen Health Sys., Inc., 459 F. Supp. 3d 1139, 1156 (N.D. Ind. 2020).

237. $I d$.

238. Id.

239. Id.

240. Id. (quoting Fridono v. Chuman, 747 N.E.2d 610, 618 (Ind. Ct. App. 2001)) (emphasis in original).

241. Id.

242. Friend v. State, 134 N.E.3d 441, 446 (Ind. Ct. App. 2019), trans. denied, 141 N.E.3d 25 (Ind.), cert. denied, 141 S. Ct. 162 (2020).

243. Id. at 445. Although the statute speaks in terms of "counselors," the applicable definition of "counselor" includes social workers. Id. at 446 (citing IND. CODE § 25-23.6-1-3.8 (2019)).

244. Id. at 446.

245. Id. at 450 (Crone, J., concurring in part and dissenting in part).

246. Id. at 451 (quoting In re Crisis Connection, Inc., 949 N.E.2d 789, 801 (Ind. 2011)). 
authorizes the disclosure of privileged information under certain circumstances, including '[c]ircumstances under which privileged communication is abrogated under Indiana law." ${ }^{247}$ Under the specific facts presented, Judge Crone believed that the privilege should have given way to the "need for fair administration of justice regarding the truth of [the] accusation." ${ }^{248}$ Both transfer and certiorari were sought and denied, ${ }^{249}$ leaving Judge Crone's perspective as a matter for future tribunals to reconsider.

\section{WITNESSES: RULES 601 THROUGH 617}

\section{A. Rule 601: Incompetency Under the Dead Man's Statute}

Rule 601 establishes that witnesses are presumed competent unless "otherwise provided in [the rules of evidence] or by statute." ${ }^{" 250}$ One such statute that renders persons incompetent to testify is Indiana's Dead Man's Statute. ${ }^{251}$ The statute "establishes as a matter of legislative policy that claimants to the estate of a deceased person should not be permitted to present a court with their version of their dealings with the decedent." ${ }^{252}$

The general purpose of the Dead Man's Statute is to protect a decedent's estate from spurious claims. The statute does not render the surviving party incompetent for all purposes; instead, its application is limited to circumstances in which the decedent, if alive, could have refuted the testimony of the surviving party. ${ }^{253}$

With modern estate planning practices having focused heavily on creating non-probate mechanisms to transfer generational wealth, ${ }^{254}$ the Indiana Court of Appeals' opinion in Bergal v. Bergal is a decision with which all lawyers

247. Id. ("Friend argues (persuasively, in my view) that this "catchall exception illustrates the Legislature anticipated that some interests will trump the need for counselor-client confidentiality, thus clearly distinguishing this case from [Crisis Connection].'” (alteration in original)).

248. Id. at 452.

249. Friend v. State, 141 N.E.3d 25 (Ind.), cert. denied, 141 S. Ct. 162 (2020).

250. IND. R. EvID. 601; see also IND. CODE § 34-45-2-1 (2021) (“All persons, whether parties to or interested in the suit, are competent witnesses in a civil action or proceeding, except as otherwise provided.").

251. IND. CODE $§ 34-45-2-4$.

252. In re Living Tr. Agreement of Morningstar, 136 N.E.3d 1139, 1153 n.15 (Ind. Ct. App. 2019) (citation omitted).

253. Bergal v. Bergal, 153 N.E.3d 243, 254 (Ind. Ct. App.) (citation and internal quotation marks omitted), reh'g denied (Sept. 17, 2020), trans. denied, 166 N.E.3d 904 (Ind. 2021); see also In re Estate of Hall, 149 N.E.3d 628, 635 n.4 (Ind. Ct. App. 2020).

254. See Terry L. Turnipseed, Why Shouldn't I Be Allowed to Leave My Property to Whomever I Choose at My Death? (Or How I Learned to Stop Worrying and Start Loving the French), 44 BRANDEIS L.J. 737, 748 (2006). 
routinely involved in estate disputes should acquaint themselves. ${ }^{255}$ At issue was whether the Dead Man's Statute applied to a dispute over assets held in a trust that was established as part of an estate plan. ${ }^{256}$ The appellate court found that the Trust at issue "was the primary piece of [the decedent]'s overall estate plan" with his will having been "created at the same time as the Trust" and as "a pour over Will, which said that if [the decedent] owned anything in his name it would pour over into the Trust so that everything would be in the Trust ultimately at the time of his death." ${ }^{257}$ Because the trust was "sufficiently related to probate that the outcome of this case will affect his overall estate," such that it "is so central to [the] overall estate plan that it is akin to the estate itself," the court concluded that the Dead Man's Statute properly applied. ${ }^{258}$

Notably, the appellate court also found no problem applying the statute even though "no executor or administrator" was a party to the action. ${ }^{259}$ Despite the Dead Man's Statute explicitly requiring "an executor or administrator [be] a party," 260 the court of appeals "has [previously] held that even if an administrator or executor is not a party to the action, the Dead Man's Statute applies where one of the parties is acting in the capacity of an administrator or executor."261 Extending that concept, the court had "little difficulty concluding that . . . the trustee of the Trust . . . [was] acting in the capacity of an administrator or executor." 262

\section{B. Rule 609(b): Probation Does Not Constitute "Confinement"}

Rule 608 generally governs the circumstances in which a witness's character may be challenged. ${ }^{263}$ Subdivision (a) controls character evidence based on a person's reputation within a specific community. ${ }^{264}$ Subdivision (b) narrows the focus to "specific instances of a witness's conduct in order to attack or support the witness's character for truthfulness." 265 But Rule 608(b) excludes from its province prior criminal convictions. ${ }^{266}$ Instead, those specific instances of conduct are carved out of Rule 608 and made subject to the dictates of Rule $609 .{ }^{267}$

255. Bergal, 153 N.E.3d at 253-56.

256. Id. at 254 .

257. Id. at 255 .

258. Id. at $255-56$.

259. Id. at $254 \mathrm{n} .10$.

260. IND. CODE § 34-45-2-4(a)(1) (2021).

261. Bergal, 153 N.E.3d at 254 n.10 (citing In re Harris, 876 N.E.2d 1132, 1135 (Ind. Ct. App. 2007)).

262. Id.

263. IND. R. EVID. 608.

264. InD. R. EviD. 608(a); Dynes v. Dynes, 637 N.E.2d 1321, 1322-23 (Ind. Ct. App.), trans. denied (Ind. 1994).

265. IND. R. EvID. 608(b).

266. See id.

267. Id. ("Except for a criminal conviction under Rule 609 ... ."); IND. R. EvID. 609. 
The use of prior convictions is heavily circumscribed, with the conviction being admitted "only if the crime committed or attempted is (1) murder, treason, rape, robbery, kidnapping, burglary, arson, or criminal confinement; or (2) a crime involving dishonesty or false statement, including perjury." ${ }^{268}$ Even then, further limitations apply "if more than ten (10) years have passed since the witness's conviction or release from confinement for it, whichever is later."'269

Importantly, the further limitation created by Rule 609(b) is not merely that ten years have passed since the date of conviction; rather, ten years need to have passed since the later date of the witness's conviction or confinement. The question of what constitutes "confinement" has become more important as "noncustodial sanctions such as fines or probation" have become increasingly commonplace. ${ }^{270}$ Resolution of that question was at the core of the Indiana Court of Appeals' opinion in Chapman v. State. ${ }^{271}$ At his May 2019 trial, the State successfully sought to use Chapman's August 2008 conviction for false informing against him. ${ }^{272}$ Based on that information alone, it would appear that the conviction was outside the permissible ten-year window to use it as a matter of course. The trial court was not, however, a poor student of arithmetic. Instead, the rationale for the trial court permitting the use of the conviction was that Chapman "had been sentenced to 180 days suspended, with one year of unsupervised probation, which had been completed on September 1, 2009."273 The threshold question of whether the conviction was subject to Rule 609(b) thus turned on whether probation constituted "confinement." The trial court determined that it did "and preliminarily ruled that Chapman's prior conviction would be admissible if Chapman chose to testify." ${ }^{274}$

The court of appeals disagreed. ${ }^{275}$ Acknowledging that "Evidence Rule 609(b) does not define 'confinement,' and that Indiana appellate courts have not specifically addressed whether probation qualifies as confinement under Rule 609(b)," the court turned to Black's Law Dictionary for an operative definition: "[t]he act of imprisoning or restraining someone; the quality, state, or condition of being imprisoned or restrained." ${ }^{276}$ The court put further use to Black's Law Dictionary as one of two sources to define "probation": "[a] court-imposed criminal sentence that, subject to stated conditions, releases a convicted person into the community instead of sending the criminal to jail or prison." 277 Because

268. IND. R. EvID. 609(a).

269. IND. R. EVID. 609(b).

270. Alice Ristroph, The Curriculum of the Carceral State, 120 CoLuM. L. REV. 1631, 1697 (2020).

271. Chapman v. State, 141 N.E.3d 881 (Ind. Ct. App. 2020), trans. not sought.

272. Id. at 883 .

273. Id.

274. Id.

275. Id. at 886 .

276. Id. (quoting Confinement, Black's LAW DictionARY (10th ed. 2014)).

277. Id. (quoting Probation, Black's LaW Dictionary (10th ed. 2014)). By way of parenthetical quotation, the court also cited Abernathy v. State, 852 N.E.2d 1016, 1020 (Ind. Ct. 
Chapman "was not actually imprisoned," the court determined, "he was not confined" within the meaning of Rule 609(b). ${ }^{278}$ The court's conclusion was buttressed by a similar finding of the Seventh Circuit in United States $v$. Rogers. ${ }^{279}$

Observant readers will note that merely falling outside the ten-year window does not render a conviction inadmissible per se. Rather, it renders the conviction otherwise admissible in accordance with Rule 609(a) only "presumptively inadmissible"280 and may still be admitted so long as: "(1) its probative value, supported by specific facts and circumstances, substantially outweighs its prejudicial effect; and (2) the proponent gives an adverse party reasonable written notice of the intent to use it so that the party has a fair opportunity to contest its use." ${ }^{281}$ The court of appeals found that the requisite showing both of probative value and reasonable notice were not established to overcome the presumption because the trial court had not engaged in the balancing test necessary to assess the probative value "and the State [otherwise] failed to provide reasonable written notice, ${ }^{282}$ having apparently first given notice on the day of trial. ${ }^{283}$

\section{Rule 611: Examining Witnesses}

"Indiana Evidence Rule 611 [ ] governs the mode and order of examining witnesses and presenting evidence." 284 In Moriarty v. Moriarty, the Indiana Court of Appeals affirmed the trial court's decision to reopen a case-in-chief to call the

App. 2006) ("Probation is a criminal sanction wherein a convicted defendant specifically agrees to accept conditions upon his behavior in lieu of imprisonment.").

278. Chapman, 141 N.E.3d at 886.

279. Id. (citing United States v. Rogers, 542 F.3d 197, 201 (7th Cir. 2008)); see also id. at 888 (Crone, J., concurring in result) (finding further support in the history of Indiana Evidence Rule 609(b) and the corresponding Federal Rule of Evidence).

280. Id. at 887 .

281. IND. R. EvID. 609(b).

282. Chapman, 141 N.E.3d at 887.

283. Id. at 883. It is actually unclear from the appellate opinion as to when the State advised Chapman of the intent to use his conviction against him. The only detail provided in the opinion states, "On May 29, 2019, the case proceeded to a jury trial. Prior to the commencement of jury selection, the State informed the trial court that Chapman had been convicted of false informing on August 24, 2008 and had been sentenced to 180 days suspended, with one year of unsupervised probation, which had been completed on September 1, 2009." Id . Notably, that only states when the trial court was informed. A review of the appellate briefs does not resolve the matter either. See Appellant's Brief at 11, Chapman v. State, 141 N.E.3d 881 (Ind. Ct. App. 2020) (No. 19A-CR1636) ("Prior to the commencement of trial, the State raised its intent to introduce such evidence in the event Chapman were to testify."); see also Appellee's Brief at 16, Chapman v. State, 141 N.E.3d 881 (Ind. Ct. App. 2020) (No. 19A-CR-1636) (not challenging adequacy of notice, simply contending the argument was waived for failure to object on that basis to trial court).

284. Moriarty v. Moriarty, 150 N.E.3d 616, 628 (Ind. Ct. App.), trans. denied, 159 N.E.3d 566 (Ind. 2020). 
defendant as an additional witness. ${ }^{285}$ " $[\mathrm{I}] \mathrm{t}$ is within the discretion of the trial court to permit a party to present additional evidence or testimony once the party has rested, once both parties have rested, or after the close of all of the evidence." ${ }^{286}$ The appellate court affirmed, despite the lower court not specifically considering the factors laid out in Flynn v. State. ${ }^{287}$ Bolstering the decision was that the trial court specifically acknowledged the role of Rule 611 in its determination, "explain[ing] that the rule required it to "exercise reasonable control over the mode and order of examining witnesses and presenting the evidence so as to make those procedures effective for determining the truth, avoid wasting time, and protecting witnesses from harassment and undue embarrassment.",288

Rule 611 establishes the traditional order for examination of witnesses and presentation of evidence. ${ }^{289}$ Nevertheless, there is conduct that may occur within the examination of a witness that "opens the door" to questioning or evidence that would otherwise be impermissible. ${ }^{290}$ "Opening the door refers to the principle that where one party introduces evidence of a particular fact, the opposing party is entitled to introduce evidence in explanation or rebuttal thereof, even though the rebuttal evidence otherwise would have been inadmissible." ${ }^{291}$ In order for the door to be opened to permit otherwise inadmissible testimony or examination, the trier of fact must be left "with a false or misleading impression of the facts." 292

During the survey period, the Indiana Court of Appeals upheld findings that the door had been opened where a police sergeant was cross-examined on the contents of photographs, thereby allowing him to testify on redirect of his opinions regarding the contents of the photographs ${ }^{293}$; and, where a detective was asked on cross-examination why he had not interviewed persons who an informant had told him may have committed the murder, the officer was permitted to explain why they had been eliminated as suspects on redirect. ${ }^{294} \mathrm{~A}$ third appellate opinion found whether questioning had properly opened the door a tougher question. In a split decision, the majority of the appellate panel concluded that the door had been opened to provide evidence regarding child abuse syndrome because the child witness's credibility had been called into

285. Id. at 626-28.

286. Id. at 626-27 (citations omitted).

287. Id. at 627 (discussing Flynn v. State, 497 N.E.2d 912 (Ind. 1986)).

288. Id. at 628 .

289. IND. R. EvID. 611.

290. See, e.g., Stokes v. State, 908 N.E.2d 295, 301-02 (Ind. Ct. App.) (analyzing opening the door as a facet of Rule 611(b)), trans. denied, 919 N.E.2d 559 (Ind. 2009); Spaulding v. Harris, 914 N.E.2d 820, 833 (Ind. Ct. App. 2009) (same), trans. denied, 929 N.E.2d 788 (Ind. 2010).

291. Garcia-Berrios v. State, 147 N.E.3d 339, 343 (Ind. Ct. App.) (citations omitted), trans. denied, 150 N.E.3d 1025 (Ind. 2020).

292. Id.; Flowers v. State, 154 N.E.3d 854, 870 (Ind. Ct. App. 2020).

293. Flowers, 154 N.E.3d at 870-71.

294. Garcia-Berrios, 143 N.E.3d at 343-44. 
question by counsel for the defendant's opening statement. ${ }^{295}$ In dissent, Judge L. Mark Bailey "acknowledge[d] that counsel called [the child] a liar in her opening statement and that comments by counsel can sometimes open a door."296 Nevertheless, Judge Bailey did "not believe that the bald assertion by defense counsel [was sufficient to] open[ ] the floodgates" to the same degree the majority had. ${ }^{297}$

\section{Rule 613: Witness's Prior Statement}

"Rule 613 allows the use of a prior inconsistent statement to impeach a witness, and when so used, the statement is not hearsay." 298 Before a prior inconsistent statement may be admitted, "the witness [must be] given an opportunity to explain or deny the statement and an adverse party [must be] given an opportunity to examine the witness about it, or if justice so requires," unless the statement is that of an opposing party under Rule 801(d)(2). ${ }^{299}$

The purpose of [this procedure] is to allow a lawyer to ask a witness whether he made a certain statement and, if the witness answers 'no', the lawyer can then try to prove that the witness indeed made the statement, but the witness must at that point be given an opportunity to explain or deny it, i.e. to rebut the cross-examiner's proof. ${ }^{300}$

As a result, "if the witness has already acknowledged the prior inconsistent statement on cross-examination," the "prior inconsistent statement is not admissible under Rule 613 . . . because impeachment is complete after such an acknowledgment." ${ }^{301}$

In an appeal of conviction for the death of a one-year-old child, the Indiana Court of Appeals ruled that the trial court had correctly applied Rule 613 to prohibit admission of a witness's prior videotaped interview because the witness had "acknowledged having made inconsistent statements . . . and offered explanations for why he had done so." ${ }^{302}$ In that instance, the criminal

295. Pierce v. State, 135 N.E.3d 993, 1004-05 (Ind. Ct. App. 2019), trans. denied, 143 N.E.3d 955 (Ind. 2020).

296. Id. at 1008 (Bailey, J., dissenting).

297. Id.

298. Jackson v. State, 925 N.E.2d 369, 375 (Ind. 2010) (citation omitted); see also IND. CoDE § 34-45-4-1 (2021).

299. IND. R. EVID. 613(b).

300. United States v. Johnson, 965 F.2d 460, 465 (7th Cir. 1992) (citations and further internal quotation marks omitted).

301. Shepherd v. State, 157 N.E.3d 1209, 1220 (Ind. Ct. App. 2020) (citation omitted), trans. denied, 165 N.E.3d 67 (Ind. 2021).

302. Id. The outcome may well have been different had the prior statement been a deposition. Indiana Trial Rule 32(A)(1) establishes that "[a]ny deposition may be used by any party for the purpose of contradicting or impeaching the testimony of deponent as a witness." IND. T.R. 32(A)(1). Shortly after the close of the survey period, the Indiana Supreme Court amended Trial 
"defendant's [constitutional] right to cross-examine the witnesses against him" was not undermined by adherence to Rule 613 because "the Confrontation Clause only guarantees an opportunity for effective cross-examination; it does not guarantee cross-examination in whatever manner or extent desired by a defendant." ${ }^{\text {"303 }}$ The witness was present and testified live, allowing "the jury [ ] a first-hand opportunity to assess [his] credibility." 304

While Rule 613 is generally known as the conduit for introducing prior inconsistent statements, it is not confined to inconsistent statements. "To be admissible as substantive evidence, [a] prior consistent statement must have been made before the motive to fabricate arose." ${ }^{305}$ The Indiana Court of Appeals ruled that a prior statement by an alleged victim of child molestation was not properly admitted where the allegations of molestation were first asserted the night after the defendant informed the alleged victim's mother of his intent to divorce her. ${ }^{306}$

\section{E. Rule 615: Separation of Witnesses}

Although orders separating witnesses during trial are common, two cases before the Indiana Court of Appeals proved that there still remain unsettled issues in the practice. "In general, a separation of witnesses order is governed by Indiana Evidence Rule 615." ${ }^{\prime 307}$ The rule requires, upon request of a party, the exclusion of witnesses from being present during the presentation of testimony at trial. ${ }^{308}$ The court may also, of its own accord, order the witnesses separated. ${ }^{309}$ The rule does not, however, permit exclusion of "a party who is a natural person," a designated officer or employee of a non-natural person, ${ }^{310}$ or "a person whose presence a party shows to be essential to presenting the party's claim or defense." "311 "The purpose of Rule 615 is that witnesses should be insulated from the testimony of other witnesses." ${ }^{312}$

Rule 32(A)(2) to further clarify the clear command of Rule 32(A)(1) that the deposition "may be used . . . for any purpose, regardless of the presence or absence of the person deposed." Order Amending Indiana Rules of Trial Procedure, No. 20S-MS-1 (Ind. Nov. 12, 2020).

303. Shepherd, 157 N.E.3d at 1220.

304. Id.

305. Reynolds v. State, 142 N.E.3d 928, 940-41 (Ind. Ct. App.) (citations and internal quotation marks omitted), trans. denied, 149 N.E.3d 597 (Ind. 2020).

306. Id. at 941 .

307. Harris v. State, 148 N.E.3d 1107, 1111 (Ind. Ct. App. 2020), trans. granted and opinion vacated, 165 N.E.3d 91 (Ind. 2021).

308. IND. R. EvID. 615.

309. Id.

310. This also applies to the state, which may take the form of the investigating police officer in prosecutions. 13B Robert L. Miller, Jr., Indiana Practice: Courtroom Handbook on IndiAnA EvidENCE 615 (2020-2021 ed.); see, e.g., Tavake v. State, 131 N.E.3d 696, 705 (Ind. Ct. App.), trans. denied, 134 N.E.3d 1021 (Ind. 2019).

311. IND. R. EVID. 615.

312. In re K.L., 137 N.E.3d 301, 306 (Ind. Ct. App. 2019) (citations and quotation marks 
The question of when a party must request a separation of witnesses for it to be effective arose in In re K.L. ${ }^{313}$ It was not until the start of the second day of trial that a mother in an action to terminate her parental rights requested separation of witnesses. ${ }^{314}$ "The juvenile court denied the motion as untimely and the remaining witnesses testified in the presence of each other." ${ }^{315}$ Although the appellate court ultimately affirmed the termination of parental rights, it did find error in the lower court's denial of the mother's motion:

To effectively serve [Rule 615's] purpose, a motion for separation of witnesses should ideally be made before any witness testifies. However, Rule 615 does not address when such a motion must be made. Therefore, a motion made after testimony has begun may be permissible as long as basic notions of fundamental fairness are not offended. Here, one witness testified on the first day of the termination hearing and only put on enough evidence to secure venue and jurisdiction[.] Mother requested a separation of witnesses order at the outset of the second day of the termination hearing before any other witnesses had been called. Accordingly, the timing of Mother's motion did not affect the fundamental fairness of the proceeding and the juvenile court should have granted the motion and ordered separation of the witnesses. ${ }^{316}$

Later in the survey period, a question of "first impression-whether the parent of a juvenile waived to adult court is subject to a separation of witnesses order" - came before the Indiana Court of Appeals. ${ }^{317}$ In a split decision, the majority of the panel concluded that the special status accorded juvenile defendants, owing to their immaturity, ensured the "need for meaningful consultation with a parent regarding the juvenile's rights remain[s]," even when the juvenile is subject to trial as an adult. ${ }^{318}$ "As such, [the majority] conclude[d] that the parent of a juvenile waived to adult court is 'a person whose presence a party shows to be essential to presenting the party's claim or defense."”319

Judge Vaidik's dissent largely rejected the majority's rationale in all respects. ${ }^{320}$ She first contended that the argument had been waived by the failure to raise the Rule 615 argument to the trial court. ${ }^{321}$ Perhaps more telling, in Judge Vaidik's esteem, the defendant did "not argue on appeal that his mother should have been allowed to stay in the courtroom because of Evidence Rule 615(c).

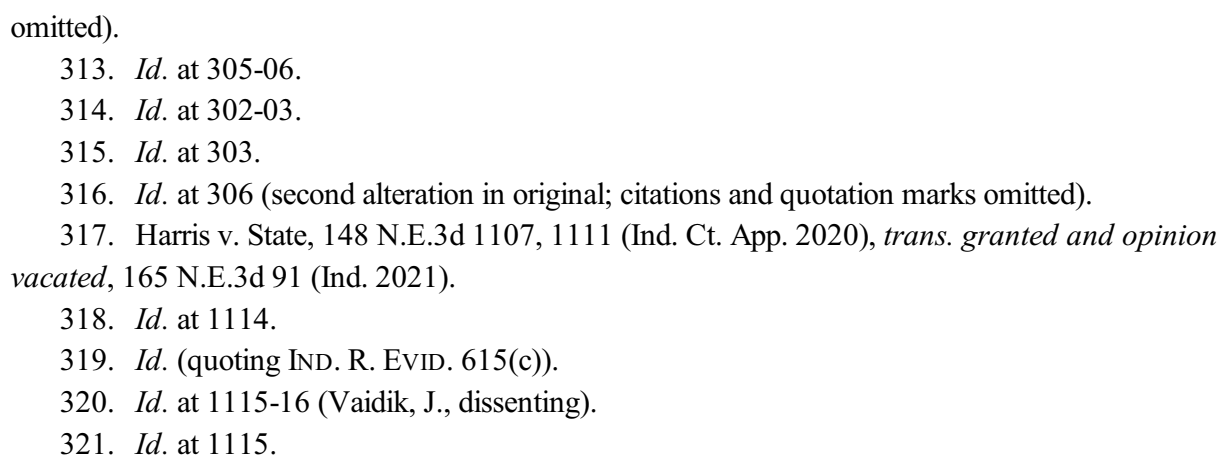


Instead, he argues that he had a right to have his mother in the courtroom in spite of Evidence Rule 615." ${ }^{22}$ But, waiver aside, Judge Vaidik "disagree[d] with the majority's blanket conclusions that every waived juvenile has an absolute dueprocess right to have a parent who is also a witness present throughout trial and that the presence of such a parent is per se 'essential' for purposes of Rule 615 (c)." ${ }^{323}$ Instead of a blanket rule, she would have held that the juvenile "be required to make some showing of need" for the parent to be present. ${ }^{324}$

At the close of the survey period, the Indiana Supreme Court granted transfer, thereby vacating the court of appeals' decision. ${ }^{325}$ The Indiana Supreme Court's resolution will be taken up in the next survey.

\section{F. Rule 616: Witness's Bias}

"Indiana Evidence Rule 616 explicitly makes 'evidence of bias, prejudice, or interest of the witness for or against any party' relevant and admissible for impeachment purposes, as this evidence can impact the weight of the witness's testimony." 326 Examining the scope of Rule 616, the Indiana Court of Appeals rebuffed a challenge to a conviction for child molestation alleging erroneous exclusion of evidence relating to the victim's biases. ${ }^{327}$ The defendant argued that he should have been permitted to enter evidence that the victim "once stole money from another person; ... once falsely said that their dog was dead; and . . . had taken and deleted inappropriate photos of herself on a phone." 328 The appellate court determined that none of the excluded "evidence shows that [the victim] was biased against [the defendant]." 329 Instead, the evidence simply showed the victim "doing something characteristic of someone who has ongoing behavioral issues or is simply a rebellious teenager." ${ }^{330}$ The Court of Appeals, affirming the trial court, concluded:

While a party may inquire into such collateral matters on crossexamination, those collateral matters cannot be "used in a manner solely to prejudice a jury against a witness and [are] not material to the litigation[.]" These "evidentiary harpoons" are pieces of evidence that would not be independently admissible, and therefore, their admission

322. Id. (emphasis in original).

323. Id. at 1116 .

324. Id. (emphasis in original).

325. Harris v. State, 165 N.E.3d 91, 100 (Ind. 2021) ("Harris did not make the requisite showing under Evidence Rule 615(c) to establish that his mother was 'essential' to the presentation of his defense, nor did he show he had a due process right to have her present."); IND. R. APP. P. 58(A).

326. Konopasek v. State, 946 N.E.2d 23, $27-28$ (Ind. 2011) (quoting IND. R. EvID. 616).

327. Friend v. State, 134 N.E.3d 441, 449-50 (Ind. Ct. App. 2019), trans. denied, 141 N.E.3d 25 (Ind.), cert. denied, 141. S. Ct. 162 (2020).

328. Id. at 449 .

329. Id.

330. Id. 
even on cross-examination is improper. ${ }^{331}$

\section{OPINIONS \& EXPERT OPINIONS: RULES 701 THROUGH 705}

\section{A. Rule 701: Opinion Testimony by Lay Witnesses}

Opinions of witnesses, other than expert opinions governed by Rule 702, are subject to the limitations of Rule $701 .{ }^{332}$ While Rule 701 ostensibly applies purely to lay witnesses, there is a category lying between that of a traditional lay witness and an expert witness that is subsumed by Indiana Evidence Rule 701: skilled witnesses.

A skilled witness is a person who possesses specialized knowledge short of that necessary to be declared an expert under Evidence Rule 702 but beyond that possessed by an ordinary juror. Not only can skilled witnesses testify about their observations, but also they can testify to opinions or inferences that are based solely on facts within their own personal knowledge. It is within the trial court's discretion to determine whether a witness is qualified to give an opinion. ${ }^{333}$

Because a skilled witness is not an expert witness, the witness's "opinion must [still] be rationally based on his perception of the facts - this simply means that the opinion must be one that a reasonable person could normally form from the perceived facts, which are facts received by the witness directly through any of his own senses." 334 Because it is not subject to the standards of Rule 702, "[s]killed witness testimony generally need only meet a relatively low bar in order to be admissible." ${ }^{335}$

Two decisions provided useful insight into the acceptable purview of skilledwitness testimony, during the survey period. In Riggle v. State, the Indiana Court of Appeals determined that an officer of the Pokagon Band Tribal Police Department who had served with the department "for over five years and is crossdeputized as a special deputy in the St. Joseph County Sheriff Department in order to be able to enforce state law on tribal property" could offer skilled-witness testimony on whether the charged offense was subject to the jurisdiction of the Pokagon Tribe or Indiana state court. ${ }^{336}$

The second decision, though not from an Indiana tribunal, helps to revitalize two prior Indiana appellate decisions, each having been reversed by a higher

331. Id. at 450 (alterations in original) (citations omitted).

332. IND. R. EviD. 701; see, e.g., Hill v. State, 137 N.E.3d 926, 942-43 (Ind. Ct. App. 2019) (finding testimony of supervising detective that it was his opinion that they had not obtained sufficient evidence in 1980 to take the file to prosecutors to prosecute defendant later tried in 2018 as appropriate lay testimony under Rule 701), trans. denied, 143 N.E.3d 949 (Ind. 2020).

333. Riggle v. State, 151 N.E.3d 766, 769 (Ind. Ct. App. 2020) (citations omitted).

334. Id. (citation omitted).

335. Id. at 772 (citation omitted).

336. Id. at 769-72. 
appellate court on other grounds. Before the Supreme Court of Kentucky was the question of whether a detective, with no expertise on the underlying technology, could testify as a lay witness regarding the location of cellular phone towers he was able to mark on a Google ${ }^{\mathrm{TM}}$ map using a report from AT\&T. ${ }^{337}$ Following the Indiana Supreme Court's opinion in Zanders v. State and the Indiana Court of Appeals' opinion in McCowan v. State, the Supreme Court of Kentucky concluded that "marking points on a graph - in these cases a map - based on a cell phone report including latitude and longitude of cell towers, does not require an expert." ${ }^{\prime 338}$

\section{B. Rule 702: Testimony by Expert Witnesses}

Unlike testimony under Rule 701, expert-opinion testimony must meet the rigors of Rule $702 .{ }^{339}$ Rule 702 establishes two requirements: "First, the subject matter must be distinctly related to some scientific field, business, or profession beyond the knowledge of the average layperson; and second, the witness must be shown to have sufficient skill, knowledge, or experience in that area so that the opinion will aid the trier of fact." ${ }^{340}$ The trial court acts as gatekeeper to "ensur[e] that an expert witness's testimony both rests on a reliable foundation and is relevant to the task at hand." 341 Nevertheless, the rule is not "intend[ed] to interpose an unnecessarily burdensome procedure for trial courts to apply when considering the admissibility of expert testimony." ${ }^{\text {"32 }}$

The 2017 Survey covered two decisions from the Indiana Court of Appeals issued within a two-week period that shaped the landscape of whether a nonphysician expert could opine on causation of injuries. ${ }^{343}$ The earlier of the two decisions, Aillones v. Minton, rejected a bright-line rule prohibiting such testimony and concluded that the distinction in training between the physician and non-physician expert was a matter for weight not admissibility of the testimony. ${ }^{344}$ The latter opinion, Totton v. Bukofchan, also rejected a per se

337. Torrence v. Commonwealth, 603 S.W.3d 214, 223-28 (Ky. 2020).

338. Id. at 227-28 (discussing Zanders v. State, 73 N.E.3d 178, 188 (Ind. 2017), cert. granted and judgment vacated, 138 S. Ct. 2702 (2018); McCowan v. State, 10 N.E.3d 522, 532 (Ind. Ct. App.), trans. granted and opinion vacated, 14 N.E.3d 44 (Ind. 2014), opinion aff'd in part and vacated in part, 27 N.E.3d 760 (Ind. 2015)).

339. Riggle, 151 N.E.3d at 769.

340. Riley v. St. Mary's Med. Ctr. of Evansville, Inc., 135 N.E.3d 946, 951 (Ind. Ct. App. 2019) (citation omitted), trans. denied, 143 N.E.3d 953 (Ind. 2020).

341. Reece v. Tyson Fresh Meats, Inc., 153 N.E.3d 1193, 1199 (Ind. Ct. App. 2020) (citation omitted).

342. Helena Agri-Enterprises, LLC v. Jones, 149 N.E.3d 282, 295-96 (Ind. Ct. App.), trans. denied, 157 N.E.3d 526 (Ind. 2020).

343. Colin E. Flora, 2017 Developments in Indiana Evidentiary Practice, 51 IND. L. Rev. 1049, 1066-67 (2018) [hereinafter 2017 Survey] (discussing Aillones v. Minton, 77 N.E.3d 196 (Ind. Ct. App. 2017); Totton v. Bukofchan, 80 N.E.3d 891, 894 (Ind. Ct. App. 2017)).

344. Id. at 1066-67 (discussing Aillones, 77 N.E.3d at 198-203). 
prohibition, but recognized a general rule that such testimony is inadmissible unless the question of causation was "not complex." inconsistency between the two decisions, the 2017 Survey asserted, "With Aillones providing no complexity limitation such as that stated in Totton, the two decisions appear to be in conflict and will need to be resolved at some point in the future." 346

The Indiana Court of Appeals, without acknowledging the distinction between Aillones and Totton, added further support for the Totton perspective in Riley v. St. Mary's Medical Center of Evansville. ${ }^{347}$ The Riley panel, citing Totton, took it as given that the issue turned on whether the question of causation was complex. ${ }^{348}$ The non-physician expert was a radiologic technologist. ${ }^{349}$ The appellate court determined that the trial court had erred by excluding the expert's testimony because the question of causation - whether injuries were caused by contrast dye infiltrating tissue - was not, in that instance, complex. ${ }^{350}$

Although Riley relied on the complexity standard of Totton, it would be premature to conclude that the conflict between Aillones and Totton has been resolved. It is likely that the panel treated Totton's complexity standard as governing simply because the parties' briefing focused on whether the causation issue was complex. ${ }^{351}$ As courts and practitioners know well, "a court won't normally accept as binding precedent a point that was passed by in silence, either because the litigants never brought it up or because the court found no need to discuss it." ${ }^{" 352}$ One possible resolution between the apparently discordant views is to treat Aillones as a general standard and Totton as the standard for medicalmalpractice actions. Aillones specifically refrained from answering "whether a nurse practitioner[ ] might be able to testify in a medical malpractice case as to medical causation. ${ }^{353}$ Both Totton and Riley were medical-malpractice actions. ${ }^{354}$ That resolution, however, appears to run afoul of the Indiana Supreme Court's assertion that "[m]edical malpractice cases are no different from other kinds of negligence actions regarding that which must be proven." 355 Thus, it appears the challenge of harmonizing Aillones with Totton and now Riley remains for another

345. Id. at 1067 (discussing Totton, 80 N.E.3d at 894).

346. Id.

347. Riley v. St. Mary's Med. Ctr. of Evansville, Inc., 135 N.E.3d 946, 950-55 (Ind. Ct. App. 2019), trans. denied, 143 N.E.3d 953 (Ind. 2020).

348. Id. at 952 (citing Totton, 80 N.E.3d at 894).

349. Id.

350. Id. at 954 .

351. See generally Brief of Plaintiffs/Appellants Nataomi Riley and Frank Riley at 30-31, Riley, 135 N.E.3d 946 (No. 20A-CR-315); Appellee's Brief at 7, Riley, 135 N.E.3d 946; Response in Opposition of Plaintiffs/Appellants Nataomi Riley and Frank Riley at 5-10, Riley, 135 N.E.3d 946.

352. Bryan A. Garner et al., The Law of Judicial Precedent 229 (2016).

353. Aillones v. Minton, 77 N.E.3d 196, 203 n.5 (Ind. Ct. App. 2017).

354. Riley, 135 N.E.3d at 948; Totton v. Bukofchan, 80 N.E.3d 891, 892 (Ind. Ct. App. 2017).

355. Bader v. Johnson, 732 N.E.2d 1212, 1216-17 (Ind. 2000). 
day.

Another area of Indiana evidentiary practice that drew attention from courts beyond the state was the issue of bloodhound evidence. In Myers v. Neal, the Seventh Circuit affirmed the district court's finding that defense counsel's failure to object to admission of bloodhound evidence in an Indiana criminal proceeding was deficient performance. ${ }^{356}$ On first blush, that may not appear to be an issue within the ambit of Rule 702. To understand the interplay, the opinion of the Southern District of Indiana, released on the final day of the 2019 Survey, must be examined. ${ }^{357}$ After acknowledging Indiana's common-law history excluding bloodhound evidence, Judge James Sweeney II was left to resolve the question of whether that common-law tradition survived "the enactment of the Indiana Rules of Evidence." ${ }^{358}$ Finding that "Indiana courts have continued to apply the common law when it is consistent with the Rules of Evidence and there is "no reason to depart from the well established common law rule," Judge Sweeney determined that Indiana courts would likely continue to follow the common-law prohibition on bloodhound evidence as based on unreliable scientific principles failing the requirements under Rule 702(b). ${ }^{359}$

Other notable takeaways from the survey period were: petitions for change of gender do not require expert medical testimony ${ }^{360}$; it was proper to exclude the testimony of an expert whose expertise was primarily of in-home daycare for children ages 3 to 5 , where the child at issue was only twenty-two months ${ }^{361}$; a trial court that engaged in whether a statistical sampling was adequate to produce reliable findings sufficiently made "a preliminary assessment of whether the underlying methodology was scientifically valid and whether the methodology properly could be applied to the facts in issue" ${ }^{362}$; and expert testimony was properly excluded where the evidence could only be relevant if the sole witness's testimony was inaccurate, making any such expert testimony merely speculative. $^{363}$

356. Myers v. Neal, 975 F.3d 611, 621 (7th Cir.), reh'g and reh'g en banc denied, No. 193158, 2020 U.S. App. LEXIS 29609 (7th Cir. 2020).

357. Myers v. Superintendent, 410 F. Supp. 3d 958, 987-1005 (S.D. Ind. 2019), rev'd and remanded on other grounds sub nom. Myers v. Neal, 975 F.3d 611 (7th Cir. 2020).

358. Id. at 1003 .

359. Id. at 1003-04 (quoting Jackson v. State, 728 N.E.2d 147, 153 (Ind. 2000)). Judge Sweeney's opinion also proved a guide for the Wisconsin Court of Appeals. Wisconsin v. Bucki, 947 N.W.2d 152, 169 (Wis. Ct. App. 2020).

360. In re Name \& Gender Change of R.E., 142 N.E.3d 1045, 1052-53 (Ind. Ct. App. 2020).

361. Wahl v. State, 148 N.E.3d 1071, 1080 (Ind. Ct. App.), trans. denied, 152 N.E.3d 595 (Ind. 2020).

362. Helena Agri-Enterprises, LLC v. Jones, 149 N.E.3d 282, 298-300 (Ind. Ct. App.), trans. denied, 157 N.E.3d 526 (Ind. 2020).

363. Reece v. Tyson Fresh Meats, Inc., 153 N.E.3d 1193, 1199-1200 (Ind. Ct. App. 2020). 


\section{Rule 703: Bases of an Expert's Opinion Testimony}

Unlike lay witnesses, whose opinions must be "rationally based on the witness's perception," 364 expert witnesses may base their "opinion[s] on facts or data in the case that the expert has been made aware of or personally observed," including "inadmissible evidence, provided that it is of the type reasonably relied upon by experts in the field." 365 Such otherwise inadmissible evidence that may be relied upon by experts include police reports used by a doctor to render a mental health diagnosis ${ }^{366}$ and findings from other physicians, a therapist, and a social worker that were a basis for a doctor's opinions that a person was suffering from dementia, lacked mental capacity to enter into financial transactions, and was acting under the undue influence of his wife. ${ }^{367}$ As the Indiana Court of Appeals recalled, experts must not be mere conduits for presenting the opinions of others. ${ }^{368}$ Nevertheless, an expert may still rely upon the opinions and work of others, provided the expert brings "his expertise to bear in reaching an opinion." "369 Accordingly, an economist properly provided an expert opinion despite relying on calculations by another because his reports and methodologies demonstrated utilization of his own expertise in formulating his opinion. ${ }^{370}$

\section{Rule 704: Opinion on an Ultimate Issue}

For those accustomed to modern practice, it is easy to forget "the ultimate issue rule, a common law evidentiary doctrine developed in the nineteenth century that forbade witnesses from giving an opinion on ultimate issues to be decided by the jury." ${ }^{371}$ Enactment of Federal Rule of Evidence 704 abolished the rule in federal courts. ${ }^{372}$ Contrary to federal courts, Indiana joined the ranks of states abandoning the ultimate issue rule prior to the adoption of the Indiana Rules of Evidence. ${ }^{373}$ Still, Indiana Evidence Rule 704 mirrors its federal

364. IND. R. EVID. 701(a).

365. IND. R. EVID. 703.

366. A.S. v. Ind. Univ. Health Bloomington Hosp., 148 N.E.3d 1135, 1139 (Ind. Ct. App. 2020).

367. Bergal v. Bergal, 153 N.E.3d 243, 258 (Ind. Ct. App.), reh'g denied (Sept. 17, 2020), trans. denied, 166 N.E.3d 904 (Ind. 2021).

368. Helena Agri-Enterprises, LLC v. Jones, 149 N.E.3d 282, 297-98 (Ind. Ct. App.), trans. denied, 157 N.E.3d 526 (Ind. 2020).

369. Id.

370. Id.

371. Deon J. Nossel, Note, The Admissibility of Ultimate Issue Expert Testimony by Law Enforcement Officers in Criminal Trials, 93 Colum. L. Rev. 231, 235 (1993).

372. United States v. Hawley, 562 F. Supp. 2d 1017, 1038-39 (N.D. Iowa 2008).

373. Indiana appears to have adopted the ultimate issue rule in Yost v. Conroy, and rejected it in DeVaney v. State. Yost v. Conroy, 92 Ind. 464, $471-72$ (1884); DeVaney v. State, 288 N.E.2d 732, 737 (Ind. 1972). See also EdWard W. Cleary et AL., MCCormick on Evidence $§ 12$ (3d ed. 1984) (discussing trend of state courts to abandon ultimate issue rule); J. ALEXANDER TANFORD \& Richard M. Quinlan, Indiana Trial Evidence Manual $§ 42.7$ (2d ed. 1987). 
counterpart and confirms that "[t]estimony in the form of an opinion or inference otherwise admissible is not objectionable just because it embraces an ultimate issue." ${ }^{374}$ Nevertheless, witnesses are not given total license to opine on all matters. Rule 704(b) bars "opinions concerning intent, guilt, or innocence in a criminal case; the truth or falsity of allegations; whether a witness has testified truthfully; or legal conclusions." ${ }^{375}$ The survey period provided examples of challenges to opinions on each of the grounds listed in Rule 704(b).

Hill v. State presented a challenge to the opinion testimony of a detective as being an opinion on the guilt of a criminal defendant. ${ }^{376} \mathrm{~A}$ complicating factor for the prosecution was a thirty-two-year gap between the commission of the charged murder and the filing of charges. ${ }^{377}$ In order to explain the delay, the prosecution inquired of the supervising detective from the initial investigation, "In your opinion, did you ever get in the 1980s the corroborating evidence that you wanted against all three of your suspects?" ${ }^{378}$ Following an objection and colloquy, the state was permitted to ask, "So based off of your opinion as the supervising detective, did you ever get the evidence that you believed you needed to corroborate all three suspects so that you would bring it down to the prosecutor's office?" ${ }^{379}$ The detective answered, "We did not have enough evidence on [another individual]. We did not have enough evidence at the time on [a third individual]. We had substantial evidence on [the defendant], a lot of evidence." 380

While "an opinion must stop short of the question of guilt," "even in criminal cases, opinion testimony may include "evidence that leads to an [incriminating] inference, even if no witness could state [an] opinion with respect to that inference." "'381 Based on a review of "the transcript as a whole," the Indiana Court of Appeals found the testimony was not impermissible because it "was not an opinion on [the defendant's] guilt,' but rather, the impediments to filing charges in 1980." ${ }^{382}$

Two other decisions from the Indiana Court of Appeals explored the second excludable category - whether a witness has testified truthfully. Testimony that either vouches for the truthfulness of the examined witness's testimony or bolsters the testimony of another "results in an invasion of the province of the jurors in determining what weight they should place upon a witness's testimony." 383 In Watson $v$. State, the court found that asking an eleven-year-old

374. IND. R. EVID. 704(a).

375. IND. R. EVID. 704(b).

376. Hill v. State, 137 N.E.3d 926, 942-43 (Ind. Ct. App. 2019), trans. denied, 143 N.E.3d 949 (Ind. 2020).

377. Id. at 930 .

378. Id. at 942 .

379. Id.

380. Id.

381. Id. at 943 (quoting Williams v. State, 43 N.E.3d 578, 581 (Ind. 2015)) (alterations in original) (emphasis omitted).

382. Id.

383. Watson v. State, 134 N.E.3d 1038, 1045 (Ind. Ct. App. 2019), trans. denied, 141 N.E.3d 
victim of child molestation whether she recalled telling another witness "the truth about what had happened," answered in the affirmative, did not amount to reversible impermissible testimony since the witness was sworn to testify truthfully and her affirmation that she had previously been truthful "was simply [her] acknowledgement that she believed her own account of events." "384

Another case more closely tiptoed the line; still, the court of appeals found no reversible error. An emergency-room physician was "asked if she believed that emergency-room patients provide accurate information." ${ }^{385}$ In reply, she stated, "For the most part, I feel like people are honest. Sometimes I ask them questions about drug abuse or alcoholism or their sexual preferences and they're very honest. I don't think that there's a reason really for people to lie when they're seeking medical care." ${ }^{386}$ The appellate panel acknowledged that the "testimony comes close to crossing the line," but it did "not quite rise to the level of impermissible vouching." 387 The physician did not directly "opine that [the victim] was telling the truth, offering [instead] only a general observation on how emergency-room patients behave based on her experience." ${ }^{388}$ Although the court concluded that the testimony did "not quite qualify as impermissible vouching," it was not testimony the court "wish[ed] to encourage . . . in the future." 389

The third category of impermissible opinion under Rule 704(b) - legal conclusions - also drew attention from the court of appeals. ${ }^{390}$ The court affirmed exclusion of proposed testimony from an expert whose "area of expertise was reading and interpreting regulations that were applicable to daycares." ${ }^{391}$ If he had been permitted to testify he "would have testified that [Indiana Family and Social Services Administration] FSSA was responsible in overseeing licensing and monitoring home daycare, and because FSSA had never cited the Wahls for a defective gate, such testimony would have been helpful in determining if the Wahls were criminally liable." ${ }^{, 392}$ Such testimony would have been little, if anything, more than "an assertion that a party has done no wrong as a matter of law, [and] that testimony is inadmissible.",393

21 (Ind. 2020).

384. Id. at $1045-46$.

385. Garber v. State, 152 N.E.3d 642, 647 (Ind. Ct. App. 2020).

386. $I d$.

387. Id. at 648 .

388. Id.

389. Id.

390. Wahl v. State, 148 N.E.3d 1071, 1080-81 (Ind. Ct. App.), trans. denied, 152 N.E.3d 595 (Ind. 2020); see also Bergal v. Bergal, 153 N.E.3d 243, 258 (Ind. Ct. App. 2020) (concluding that testimony from a doctor that a person was under the "undue influence" of his wife was not found to amount to legal conclusion once trial court struck word "undue"), reh'g denied (Sept. 17, 2020), trans. denied, 166 N.E.3d 904 (Ind. 2021).

391. Wahl, 148 N.E.3d at 1078.

392. Id. at 1080 .

393. Id. 


\section{HEARSAY: RULES 801 THROUGH 807}

\section{A. Rules 801 \& 802: Hearsay Generally Prohibited}

While it is a simple enough matter to recognize that, "[i]n general, hearsay is not admissible unless it falls within one of the hearsay exceptions or other law provides for its admissibility," 394 it can often be less simple to determine whether a statement even constitutes hearsay. Defined by Rule 801(c), "[h]earsay is 'a statement that: (1) is not made by the declarant while testifying at the trial or hearing; and (2) is offered in evidence to prove the truth of the matter asserted." "'395 An example that easily meets that definition is a detective who testified that records from the Bureau of Motor Vehicles listed a specific date of birth for a criminal defendant. ${ }^{396}$

If, however, the statement is offered for a different purpose, then it is not hearsay. ${ }^{397}$ As a result, an investigative report attached to a probable cause affidavit for a father's pending criminal charges did not constitute hearsay when introduced in a CHINS proceeding because the "report was admitted to support the reason the State charged Father with domestic battery; it was not admitted for the truth of the statements contained in the report.. ${ }^{398}$ Similarly, a statement is not hearsay unless it is an out-of-court statement. ${ }^{399}$ Thus, an explanation by a polygraph examiner of "the process he uses to score polygraph examinations and the quality control his examinations undergo" is not hearsay because it did not provide the results of the polygraph or otherwise present out-of-court statements. ${ }^{400}$

Even if evidence meets Rule 801(c)'s definition, it may still be carved out from exclusion under Rule 801(d). ${ }^{401}$ Under Rule 801(d)(1)(B), excluded from the prohibitions on hearsay are prior statements by a "declarant [who] testifies and is subject to cross-examination[,] . . . consistent with the declarant's testimony, and [ ] offered to rebut an express or implied charge that the declarant recently fabricated it or acted from a recent improper influence or motive in so

394. Wells Fargo Bank, N.A. v. Hallie, 142 N.E.3d 1033, 1037-38 (Ind. Ct. App. 2020) (citing IND. R. EvID. 802).

395. A.S. v. Ind. Univ. Health Bloomington Hosp., 148 N.E.3d 1135, 1138 n.2 (Ind. Ct. App. 2020) (quoting IND. R. EvID. 801(c)).

396. Chastain v. State, 144 N.E.3d 732, 733 (Ind. Ct. App. 2020); see also Gorby v. State, 152 N.E.3d 649, 651-52 (Ind. Ct. App. 2020) (forensic video of molestation victim is hearsay).

397. In re L.T., 145 N.E.3d 864, 870 (Ind. Ct. App. 2020).

398. Id.

399. Holden v. State, 149 N.E.3d 612, 618-19 (Ind. Ct. App.), trans. denied, 153 N.E.3d 1099 (Ind. 2020).

400. Id; see also People v. Neal, 150 N.E.3d 984, 993-1010 (Ill. App. Ct. 2020) (relying in part on Carpenter v. State, 15 N.E.3d 1075, 1076-78 (Ind. Ct. App.), trans. denied, 20 N.E.3d 852 (Ind. 2014), to find as first impression that an address on mail does not constitute hearsay).

401. Dow v. Hurst, 146 N.E.3d 990, 1001 (Ind. Ct. App.), trans. denied, 152 N.E.3d 584 (Ind. 2020). 
testifying." ${ }^{202}$ The Indiana Court of Appeals found a child-molestation victim's prior statements did not fit that carveout when first made the day after the defendant informed the victim's mother of his intent to divorce the mother because the motive for a fabrication had already arisen. ${ }^{403}$

Rule 801(d)(2) exempts from hearsay statements made by an opposing party when offered against that party. ${ }^{404}$ The subdivisions of Rule 801(d)(2) define the boundaries of what constitute a statement by a party. ${ }^{405}$ Subdivision (A) covers statements made by an individual who is a party or acting in a "representative capacity." ${ }^{" 406}$ In Lancaster $v$. State, the first subdivision was the basis for allowing one of two statements testified to by a witness who overheard a conversation between the criminal defendant and his brother ${ }^{407}$ The statements at issue were that the defendant's brother said, '“[w]e need to smoke Jessica,' meaning to kill her." ${ }^{408}$ To which, the defendant responded, "If we do her, we'll have to do them all. ${ }^{409}$ The latter statement was easily covered by subdivision (A). ${ }^{410}$

Although the first statement was not made directly by the defendant, it too was properly admitted under Rule $801(\mathrm{~d})(2) .{ }^{411}$ But, because it was a statement made by someone other than the defendant, a different subdivision applied, 801(d)(2)(B). ${ }^{412}$ That subdivision covers "adoptive admissions," statements which "the party manifested that it adopted or believed to be true." ${ }^{413}$ Due to dearth of Indiana law on adoptive admissions, the Indiana Court of Appeals turned to federal authority for guidance. ${ }^{414}$ "The federal rule governing adoptive admissions 'does not require the party to specifically adopt another person's statements, but a "manifestation of a party's intent to adopt another's statements, or evidence of the party's belief in the truth of the statements, is all that is required for a finding of adoptive admission." "'415 Since the defendant "did not deny, disagree with, or refute the statement, and even went a step further, saying that they would 'have to do them all,"' it was proper to admit the brother's statement. ${ }^{416}$

Another circumstance wherein the statements of another may be imputed to

402. IND. R. EvID. 801(d)(1)(B).

403. Reynolds v. State, 142 N.E.3d 928, 940-41 (Ind. Ct. App.), trans. denied, 149 N.E.3d 597 (Ind. 2020).

404. IND. R. EVID. 801(d)(2).

405. IND. R. EVID. 801(d)(2)(A)-(E).

406. IND. R. EvID. 801(d)(2)(A).

407. Lancaster v. State, 153 N.E.3d 1144, 1148 (Ind. Ct. App.), trans. denied, 160 N.E.3d 508 (Ind. 2020).

408. Id.

409. Id.

410. Id.

411. Id.

412. Id.; see IND. R. EvID. 801(d)(2)(B).

413. Lancaster, 153 N.E.3d at 1148 (quoting IND. R. EvID. 801(d)(2)(B)).

414. $I d$.

415. Id. (citation omitted).

416. Id. 
a party under Rule $801(\mathrm{~d})(2)$ are statements "made by the party's agent or employee on a matter within the scope of that relationship and while it existed." ${ }^{417}$ Under that standard of subdivision (D), the testimony of a medical patient as to what she had been told by an employee of a clinic was admissible in a suit against the clinic. ${ }^{418}$

Finally, even if a statement would otherwise meet the definition of hearsay under Rule 801(c) and not otherwise be excepted from its use by Rules 801(d), 803 , or 804 , it may still be admissible if the objecting party has "opened the door" to it. ${ }^{419}$ In Cornell v. State, the Indiana Court of Appeals found no error in admitting testimony that was otherwise clearly prohibited as hearsay but were necessitated because the defendant's questioning of the witness left a "misleading impression" making "[c]larification ... warranted," despite constituting otherwise inadmissible hearsay. ${ }^{420}$

\section{B. Rule 803: Hearsay Exceptions Regardless of Declarants' Availability}

Even if a statement constitutes hearsay, it may still be admitted if it satisfies an exception under either Rule 803 or $804 .{ }^{421}$ Rule 803 is the broader of the two rules, permitting admission without regard for whether the declarant is available to testify at trial. ${ }^{422}$ The Indiana Court of Appeals tackled issues relating to the exceptions for present sense impressions, ${ }^{423}$ excited utterances, ${ }^{424}$ recorded recollections, ${ }^{425}$ business records ${ }^{426}$ and public records. ${ }^{427}$

Rule 803(1) permits admission of "[a] statement describing or explaining an event, condition or transaction, made while or immediately after the declarant perceived it." ${ }^{" 428}$ The "exception is based on the assumption that the lack of time for deliberation provides reliability." ${ }^{\prime 29}$ A proponent of such evidence must establish that the statement: "(1) . . . describe[s] or explain[s] an event or condition; (2) [was made] during or immediately after its occurrence; and (3)

417. IND. R. Evid. 801(d)(2)(D); see also Dow v. Hurst, 146 N.E.3d 990, 1001 (Ind. Ct. App.), trans. denied, 152 N.E.3d 584 (Ind. 2020).

418. Blackford v. Welborn Clinic, 150 N.E.3d 687, 695 (Ind. Ct. App. 2020), trans. granted and opinion vacated, 172 N.E.3d 1219 (Ind. 2021).

419. Cornell v. State, 139 N.E.3d 1135, 1145 (Ind. Ct. App. 2020).

420. $I d$.

421. Gorby v. State, 152 N.E.3d 649, 652 (Ind. Ct. App. 2020).

422. Compare InD. R. EvID. 803, with IND. R. EvID. 804(b).

423. IND. R. EVID. 803(1).

424. IND. R. EVID. 803(2).

425. IND. R. EVID. 803(5).

426. IND. R. EVID. 803(6).

427. IND. R. EvID. 803(8).

428. IND. R. EvID. 803(1).

429. Hurt v. State, 151 N.E.3d 809, 814 (Ind. Ct. App. 2020) (citations and quotation marks omitted). 
[was] based upon the declarant's perception of the event or condition." ${ }^{430}$ The alleged victim in Hurt $v$. State did not meet those criteria because her statement was not made "during or immediately after she was injured," having "occurred at least fifteen minutes before," and "her multiple explanations for how she suffered the injuries to her nose and mouth, [demonstrated that she] had time to deliberate before" making the statement. ${ }^{431}$

Rule 803(2) embodies in the Indiana Rules of Evidence the long-established common-law exception for excited utterances. ${ }^{432}$ "An 'excited utterance' is currently defined as '[a] statement relating to a startling event or condition, made while the declarant was under the stress of excitement that it caused." ${ }^{433}$ In order to constitute an excited utterance it must be shown that:

(1) a startling event has occurred; (2) a statement was made by a declarant while under the stress of excitement caused by the event; and (3) the statement relates to the event. [It] is not a mechanical test, and the admissibility of an allegedly excited utterance turns on whether the statement was inherently reliable because the witness was under the stress of the event and unlikely to make deliberate falsifications. The heart of the inquiry is whether the declarant was incapable of thoughtful reflection. While the amount of time that has passed is not dispositive, a statement that is made long after the startling event is usually less likely to be an excited utterance. ${ }^{434}$

The same statement sought for admission under the exception for present sense impressions in Hurt was also addressed by the court of appeals under Rule 803(2). ${ }^{435}$ The prosecution contended that the statement was an excited utterance because the alleged victim was heavily "intoxicated ... and unable to reflect or make a coherent falsehood." ${ }^{436}$ The court of appeals rejected the argument, however, finding that fifteen minutes had elapsed; the video depicted that the declarant was calm until the officer "mentioned that [the defendant] might go to jail"; "[s]he gave several explanations for how her injuries occurred"; she "made the statement to the officer in response to his questioning"; and "the video from the body camera . . . shows that [she] was deliberating — albeit drunkenly —about how to respond to repeated questioning over the course of several minutes." ${ }^{437}$

430. Id.

431. Id. at 814-15. Notably, her intoxication at the time she sustained the injuries and her statement did not undermine a finding that she had time to deliberate. $I d$. at 815 ("Her ability to deliberate was hindered by her state of intoxication, but the record establishes that she was still able to consider her responses to the officer's questions.").

432. Garber v. State, 152 N.E.3d 642, 647 n.1 (Ind. Ct. App. 2020).

433. Id. (quoting IND. R. EvID. 803(2)).

434. Hurt, 151 N.E.3d at 813-14 (internal citations and quotation marks omitted).

435. $I d$.

436. Id. at 814 (citation omitted).

437. Id. (quotation marks omitted). 
Based upon those findings, she "was not under the stress of the event at the time she made her statement," placing the statement outside the scope of Rule 803(2). ${ }^{438}$

Rule 803(5) contains the exception for recorded recollections. ${ }^{439}$

[This] exception allows the admission of "[a] record that: (A) is on a matter the witness once knew about but now cannot recall well enough to testify fully and accurately; (B) was made or adopted by the witness when the matter was fresh in the witness's memory; and (C) accurately reflects the witness's knowledge." ${ }^{440}$

A foundational requirement for admission under the exception is "some acknowledgment that the statement was accurate when it was made." "T41 The prosecution in Hurt also sought to admit the alleged victim's statement as a recorded recollection under Rule 803(5). ${ }^{442}$ Because the alleged victim "did not vouch for the accuracy of her statement" at trial due to a lack of recollection stemming from her heavy intoxication, the statement could not meet the foundational prerequisite of accuracy for admission. ${ }^{443}$

Though insufficient to admit the evidence in Hurt, the exception was a sufficient basis for admitting the recording of a forensic interview in Gorby $v$. State. ${ }^{44}$ There, despite some ambiguity on whether the child victim was expressing a lack of recollection or reluctance to testify, the appellate court deferred to the judgment of the trial court, which, "after seeing and hearing" the testimony, "concluded that she could not remember the events." foundational requirement of accuracy, that the victim "denied having talked about certain things during her forensic interview" did not prohibit satisfying the accuracy requirement because she also "testified that everything she told the interviewer-including the details [she denied she had told the interviewer] — was the truth." ${ }^{446}$ It was for the trial court "to weigh that testimony against [her] denials" in assessing whether the exception applied. ${ }^{447}$

Gorby also provided an important footnote that calls into question how Rule 803(5)(A) will be applied in the future:

The State cites Impson v. State, 721 N.E.2d 1275, 1283 (Ind. Ct. App. 2000), where a panel of this Court stated that insufficient memory can be found even when a reluctant witness falsely claims lack of memory to

438. Id

439. IND. R. EVID. 803(5).

440. Hurt, 151 N.E.3d at 813 (quoting IND. R. EvID. 803(5)).

441. Id. (citation omitted).

442. Id.

443. Id.

444. Gorby v. State, 152 N.E.3d 649, 651-53 (Ind. Ct. App. 2020).

445. Id. at 652-53.

446. $I d$. at 653 .

447. Id. 
avoid answering a question. The panel cited the 1995 edition of Indiana Practice, which in turn cited the 1992 edition of McCormick on Evidence. To the extent McCormick at one time supported that proposition, it no longer does. The current edition of McCormick notes that two courts (the Sixth Circuit in 1978 and the Pennsylvania Supreme Court in 1981) have held that reluctance to testify can satisfy the insufficient-memory requirement, but it is otherwise skeptical of the proposition. 2 McCormick on Evidence $\S 282$ (8th ed. 2020). We share that skepticism. Reluctance to answer a question simply is not the same as lack of memory, which is what Evidence Rule 803(5)(A) expressly requires. ${ }^{448}$

While that skepticism did not alter the outcome of Gorby, it opens the door to future challenges. That is especially true under Indiana appellate procedure, which "does not [ ] recognize horizontal stare decisis."

Rule 803(6) establishes the "business records exception to the hearsay rule." ${ }^{450}$ The exception applies if:

(A) the record was made at or near the time by - or from information transmitted by - someone with knowledge;

(B) the record was kept in the course of a regularly conducted activity of a business, organization, occupation, or calling, whether or not for profit;

(C) making the record was a regular practice of that activity;

(D) all these conditions are shown by the testimony of the custodian or another qualified witness, or by a certification that complies with Rule 902(11) or (12) or with a statute permitting certification; and

(E) neither the source of information nor the method or circumstances of preparation indicate a lack of trustworthiness. ${ }^{451}$

Additionally, "[t]o admit business records pursuant to Rule 803(6), the proponent of the exhibit must authenticate it." ${ }^{\text {"452 }}$ The rationale for the exception arises out of the perceived "reliability of business records stem[ming] . . from (1) the fact that the organization depends on them to operate, (2) the sense that they are subject to review, audit, or internal checks, and (3) the precision engendered by

448. Id. at 653 n.2.

449. In re J.J., 911 N.E.2d 659, 659 (Ind. Ct. App. 2009) (“Thus, each panel of this Court has coequal authority on an issue and considers any previous decisions by other panels but is not bound by those decisions."); accord In re Change of Gender Identification of A.B., 164 N.E.3d 167 (Ind. Ct. App. 2021) (Pyle, J., dissenting).

450. Hussain v. Salin Bank \& Tr. Co., 143 N.E.3d 322, 329 (Ind. Ct. App.), trans. denied, 152 N.E.3d 585 (Ind. 2020).

451. IND. R. EvID. 803(6).

452. Wells Fargo Bank, N.A. v. Hallie, 142 N.E.3d 1033, 1038 (Ind. Ct. App. 2020) (citation omitted). 
the repetition. ${ }^{9453}$

During the survey period, civil collection and mortgage foreclosure cases bore the brunt of the Rule 803(6) analysis. A particular area of focus was the interplay between Rule 803(6) and Trial Rule 9.2(A)(1)(b)'s requirement for the filing of an Affidavit of Debt. Setting a benchmark for the subsequent challenges was Zelman v. Capital One Bank (USA) N.A. ${ }^{454}$ Reviewing under a lower standard for appellate review, due to the appellee's failure to file a brief, ${ }^{455}$ the Indiana Court of Appeals ruled that the Affidavit of Debt attached to the complaint was insufficient to trigger the business records exception to allow admission of either the credit contract or credit card statements. ${ }^{456}$ It was further problematic that "the affiant's knowledge of the facts asserted in her affidavit '[was] limited to what she has gleaned from her review of unspecified business records,' and her affidavit is, therefore, 'based entirely upon hearsay." "457 Importantly, "the affiant's employment as a litigation support representative of Bank's affiliate does not, in itself, establish her personal knowledge of any of the facts relating to the complaint," and the affidavit "explicitly state[d]" that her knowledge was based on "facts obtained from Bank's business records," which required attachment of "sworn, certified, or self-authenticated copies of any such records upon which she relied." 458

Following on the heels of Zelman were Innovative Therapy Solutions $v$. Greenhill Manor Management, $L L C^{459}$ and Hussain v. Salin Bank \& Trust Co. ${ }^{460}$ Although Zelman was not cited by the Innovative Therapy Solutions panel, the panel's opinion resulted in a clear demarcation between sufficiency of the affidavit for admission at summary judgment, as in Zelman, and admission for the purpose of default judgment, recognizing, even where an Affidavit of Debt does not satisfy the business records exception of Rule 803(6), it may still constitute a proper part of the pleadings to form the basis for default judgment. ${ }^{461}$

The challenge in Hussain, however, proved a more complicated matter to distinguish from Zelman. ${ }^{462}$ Tackling Zelman's conclusion head-on, the Hussain panel distinguished both Zelman and another prior decision, ${ }^{463}$ by observing that

453. In re De.B., 144 N.E.3d 763, 769 (Ind. Ct. App. 2020).

454. Zelman v. Capital One Bank (USA) N.A., 133 N.E.3d 244 (Ind. Ct. App. 2019).

455. Id. at 247 ("Bank has not filed an appellee's brief. Therefore, we apply a less stringent standard of review and may reverse the grant of summary judgment if Zelman has shown prima facie error.").

456. Id. at $248-49$.

457. Id. at 249 .

458. Id. (citation omitted).

459. Innovative Therapy Sols., Inc. v. Greenhill Manor Mgmt., LLC, 135 N.E.3d 662 (Ind. Ct. App. 2019).

460. Hussain v. Salin Bank \& Tr. Co., 143 N.E.3d 322 (Ind. Ct. App.), trans. denied, 152 N.E.3d 585 (Ind. 2020).

461. Innovative Therapy Sols., 135 N.E.3d at 668.

462. Hussain, 143 N.E.3d at 329-31.

463. Id. at 329-30 (discussing Seth v. Midland Funding, LLC, 997 N.E.2d 1139, 1140-42 (Ind. 
the affiant "was not an employee of a third party who had purchased the [] debt"; rather, "[h]e was an employee of [the originator] that had merged with" the current owner of the debt. ${ }^{464}$ The affiant "was the custodian of the records for [the current owner of the debt], and the designated evidence established that he had acquired knowledge of the [] debt by personally examining the business records relating to [the] loan." ${ }^{\prime 65}$ More importantly, he "did not refer to unspecified business records as did the affiants [in the other cases]. Instead, [his] affidavit specifically identified the promissory note and mortgage to which he referred." 466 The records he referenced "were already in the record and authenticated"-i.e., the note and mortgage attached to the complaint, which were admitted to be true and accurate by the answer. ${ }^{467}$

In another collection matter, Smith v. National Collegiate Student Loan Trust, the Indiana Court of Appeals again found an affidavit supporting summary judgment to have satisfied Rule 803(6). ${ }^{468}$ A similar appeal decided in 2017 saw the court reject an affidavit by the exact same affiant. ${ }^{469}$ This time around, the problems that plagued the 2017 appeal were solved by the affidavit in Smith:

[T] he instant affidavit demonstrated, from a source and circumstances that did not indicate a lack of trustworthiness, that: (1) the business records were made at, near the time, or from information transmitted by a person with knowledge; (2) the business records were kept in the course of regularly conducted activities of Bank One and/or NCSLT; and (3) the making of the business records was a regular practice of the business activities of Bank One, NCSLT, and their loan servicers and subservicers. [The] designated materials also established the manner in which [the] Bank One educational loan was transferred to NCSLT; and that [the affiant] was familiar with the regular business practices or recordkeeping of NCSLT's subservicer [] as well as Bank One's servicer [] regarding the transfer of pooled loans and, therefore, could testify as to the reliability and authenticity of those documents. ${ }^{470}$

Understanding why Hussain and Smith succeeded where Zelman failed may prove to be invaluable for practitioners facing the challenges of civil collections.

Not every appellate decision addressing the business records exception was a collections matter. In re De.B. presented a challenge to "lab reports purporting to show the results of the parents' drug tests" in a CHINS proceeding. ${ }^{471}$ The

Ct. App. 2013)).

464. Id. at 330 .

465. Id.

466. Id.

467. Id.

468. Smith v. Nat'l Collegiate Student Loan Tr., 153 N.E.3d 222, 224-27 (Ind. Ct. App. 2020).

469. Id. at 225-26 (discussing Holmes v. Nat'l Collegiate Student Loan Tr., 94 N.E.3d 722, 724-26 (Ind. Ct. App. 2018)).

470. Id. at 227 (citation omitted).

471. In re De.B., 144 N.E.3d 763, 766 (Ind. Ct. App. 2020). 
panel of the Indiana Court of Appeals affirmed admission of the reports under Rule 803(6), but, in doing so, had to choose not to adhere to another panel's opinion, decided not even a year before. ${ }^{472}$ The prior decision, In re L.S., rejected application of the exception because, that panel believed, the lab "does not depend on these records to operate or conduct business. Rather, the [lab reports] were documented for the benefit of DCS." ${ }^{473}$ The majority of the De.B. panel ${ }^{474}$ rejected that conclusion from L.S., finding that the lab is obligated to maintain such reports for two years to maintain its certification, making such reports a crucial part of its business and satisfying the exception. ${ }^{475}$

Those familiar with last year's survey will recall that L.S. was not without opposition even before De.B. ${ }^{476}$ Another panel also had rejected L.S. in In re $K . R .{ }^{477}$ Unlike either L.S. or De.B., transfer of K.R. was sought to the Indiana Supreme Court to resolve the split in authority. ${ }^{478}$ Shortly after the close of the survey, the court issued its opinion siding with the panels in De.B. and K.R., rejecting $L . S .{ }^{479}$

Rule 803(8) generally grants a hearsay exception for public records. ${ }^{480}$ It does not, however, provide a conduit for admitting:

(i) investigative reports by police and other law enforcement personnel, except when offered by an accused in a criminal case;

(ii) investigative reports prepared by or for a public office, when offered by it in a case in which it is a party;

(iii) factual findings offered by the government in a criminal case; and

(iv) factual findings resulting from a special investigation of a particular complaint, case, or incident, except when offered by an accused in a criminal case. ${ }^{481}$

Departing from her colleagues, Judge Elizabeth Tavitas concurred in the result of In re L.T., but did not agree with the majority's conclusion that a probable cause affidavit was offered for a purpose other than the truth of the matter asserted, making it hearsay, absent an applicable exclusion. ${ }^{482}$ If the affidavit was,

472. Id. at 770-71 (distinguishing In re L.S., 125 N.E.3d 628, 634 (Ind. Ct. App. 2019), trans. not sought).

473. Id. at 769 (quoting L.S., 125 N.E.3d at 634).

474. Judge Edward Najam, Jr., who was a member of the L.S. panel, concurred only in the result but without separate opinion.

475. In re De.B., 144 N.E. $3 \mathrm{~d}$ at 770 .

476. See 2019 Survey, supra note 34, at 936-37.

477. In re K.R., 133 N.E.3d 754, 761-62 (Ind. Ct. App. 2019), trans. granted and opinion vacated, 154 N.E.3d 818 (Ind. 2020).

478. Id.

479. In re K.R., 154 N.E.3d at 821-22.

480. IND. R. EVID. 803(8)(A).

481. IND. R. Evid. 803(8)(B).

482. In re L.T., 145 N.E.3d 864, 872-73 (Ind. Ct. App. 2020) (Tavitas, J., concurring in result). 
as Judge Tavitas believed, hearsay, Rule 803(8)(B) dictated that it was inadmissible hearsay. ${ }^{483}$

\section{Rule 804: Hearsay Exceptions for Unavailable Declarants}

The key distinction between the hearsay exceptions of Rules 803 and 804 is that Rule 804 necessitates the declarant be unavailable. ${ }^{484}$ A textbook example of unavailability is through death of the witness prior to trial. ${ }^{485}$ Another example occurs when a witness who properly invokes her Fifth Amendment privilege becomes "an unavailable witness pursuant to Indiana Evidence Rule 804(a)." That is true even if the privilege is invoked by a defendant who then seeks to admit a statement she made to officers under a Rule 804 exception. ${ }^{487}$ When assessing whether witnesses are unavailable "the pertinent question [is] not whether the witnesses [a]re unavailable on a larger scale; it [is] whether they [a]re unavailable for the trial scheduled"; that the witness would have been unavailable for a prior trial setting is, standing alone, insufficient to demonstrate that a witness is unavailable for a rescheduled trial date. ${ }^{488}$

Once a witness has been shown to be unavailable for trial, the proponent of hearsay evidence must still establish an exception under Rule 804(b). Three decisions from Indiana courts provide brief guidance into several exceptions under Rule 804(b). In Hill v. State, the Indiana Court of Appeals concluded that even though a deposition did not focus on a murder investigation, because "several questions were asked regarding the murder investigation," the motive requirement of Rule 804(b)(1)(B) for admitting former testimony was satisfied. ${ }^{489}$

483. Id. at 873 .

484. IND. R. EVID. 804(b).

485. See, e.g., Hill v. State, 137 N.E.3d 926, 931, 938 (Ind. Ct. App. 2019), trans. denied, 143 N.E.3d 949 (Ind. 2020).

486. Hughes v. State, 153 N.E.3d 354, 359 (Ind. Ct. App.), trans. denied, 159 N.E.3d 567 (Ind. 2020); accord United States v. Salerno, 505 U.S. 317, 321 (1992); United States v. Nagib, 56 F.3d 798, 804 (7th Cir. 1995).

487. Webb v. State, 149 N.E.3d 1234, 1239 (Ind. Ct. App. 2020) ("The State argues Webb cannot both claim unavailability to introduce a statement she made to officers and, at the same time, exercise her right against self-incrimination to avoid being cross-examined about the statement. However, despite the State's objection, Webb's declaration of her Fifth Amendment constitutional right against self-incrimination is a valid and protected privilege that does meet the criteria for unavailability.").

488. Noelker v. State, 148 N.E.3d 345, 352 (Ind. Ct. App.) (finding prosecution prejudiced by defendant refusing to sign stipulation one week prior to trial that would have made witnesses unnecessary), trans. denied, 152 N.E.3d 591 (Ind. 2020).

489. Hill, 137 N.E.3d at 938. Of further note in applying Rule 804(b)(1)'s exception for former testimony, shortly after the close of the survey period, the Indiana Supreme Court amended Indiana Trial Rule 32(A)(2) to clarify that a deposition "may be used by an adverse party for any purpose, regardless of the presence or absence of the person deposed." Order Amending Indiana Rules of Trial Procedure, No. 20S-MS-1 (Ind. Nov. 12, 2020) (emphasis added). 
Rule 804(b)(3)'s exception for statements against interest was also examined by the court of appeals in Webb v. State. ${ }^{490}$ "Statements against interest are admissible because they tend to expose the declarant to criminal liability, and thus a reasonable person in the declarant's position would not have made the statements if she did not believe them to be true." ${ }^{491}$ To constitute a "statement against interest," the statement "must be incriminating on its face[;] . . . it is not enough that a statement merely arouse some suspicion as to culpability in the factual context of the case." ${ }^{\prime 42}$ As a result, the Webb defendant's attempted use of statements made by her to an officer as the sole evidence to claim she had permission to possess the purportedly stolen items did not meet the criteria for the 804(b)(3) exception because the "statement is more exculpatory than inculpatory." ${ }^{493}$

The same exception was further discussed by the United States District Court for the Southern District of Indiana in Brown v. Brown. ${ }^{494}$ Addressing application of Indiana Evidence Rule 804(b)(3), the court considered whether a codefendant's statement to another jail inmate should have been excluded at trial. ${ }^{495}$ Although the statements would have been properly admissible under the statement-against-interest exception if offered against the co-defendant, because the statement implicated the defendant and was not a statement originating from the defendant, it was inadmissible hearsay. ${ }^{496}$

\section{Rule 805: Hearsay Within Hearsay}

It is not always sufficient to find a single exception to the general prohibition on hearsay of Rule 802. If evidence contains multiple layers of hearsay, just like peeling an onion, the proponent of that evidence must be able to proceed layer by layer, providing an exception for each. ${ }^{497}$ In a concurring opinion, Judge Tavitas departed from her colleagues on the Indiana Court of Appeals by concluding that a probable cause affidavit used as evidence in a CHINS proceeding was offered for the truth of the matter asserted, thereby constituting hearsay under Rule

490. Webb, 149 N.E.3d at 1240-41.

491. Id. at 1240 (citation omitted).

492. Id. (citations and quotation marks omitted).

493. Id. at $1240-41$.

494. Brown v. Brown, 471 F. Supp. 3d 866, 873-74 (S.D. Ind. 2020), appeal dismissed sub nom. Brown v. Vanihel, 7 F.4th 666 (7th Cir. 2021).

495. Id. at 873 .

496. Id. at 873-74.

497. IND. R. EvID. 805 ("Hearsay within hearsay is not excluded by the rule against hearsay if each part of the combined statements conforms with an exception to the rule."); see, e.g., Dow v. Hurst, 146 N.E.3d 990, 1001 n.7 (Ind. Ct. App.) (“Even if hearsay, Mrs. Hurst's testimony was not hearsay-within-hearsay or 'double hearsay' because Dow's statements to Parker were the statement of a party opponent and therefore not hearsay as defined by Indiana Evidence Rule 801(d)(1).”), trans. denied, 152 N.E.3d 584 (Ind. 2020). 
801(c). ${ }^{498}$ Having concluded that the affidavit's use fell within the scope of hearsay, Judge Tavitas next considered whether any hearsay exceptions applied to permit the affidavit's admission. ${ }^{499}$ As the product of the work and observations of other investigative officers and DCS, the statements contained within the probable cause affidavit constituted hearsay within hearsay for which no requisite exceptions applied. ${ }^{500}$

Although Judge Tavitas's concurrence is not binding, it demonstrates important insight into the inherent double-hearsay problems that arise with use of probable cause affidavits, provided the court deems the particular use of the affidavit to be for the truth of the matters asserted therein. ${ }^{501}$

\section{AUTHENTICATION \& IDENTIFICATION: RULES 901 THROUGH 903}

\section{A. Rule 901: Authenticating or Identifying Evidence}

To be admissible, "[w]ritings and recordings must be authenticated pursuant to Indiana Evidence Rule 901(a)."502 "To satisfy the requirement of authenticating or identifying an item of evidence, the proponent must produce evidence sufficient to support a finding that the item is what the proponent claims it is."${ }^{, 503}$

Absolute proof of authenticity is not required. Rather, the proponent of the evidence must establish only a reasonable probability that the evidence is what it is claimed to be. Once this reasonable probability is shown, any inconclusiveness regarding the exhibit's connection with the events at issue goes to the exhibit's weight, not its admissibility. Additionally, authentication of an exhibit can be established by either direct or circumstantial evidence. ${ }^{504}$

To aid practitioners and courts in implementing Rule 901(a)'s general requirement for authenticity, "Rule 901(b) provides a [non-exhaustive] list of examples of evidence that satisfy the requirement of subsection (a)." 505

As has become common, ${ }^{506}$ the Indiana Court of Appeals once more had to address a rule that predates modern technological norms in light of decades of

498. In re L.T., 145 N.E.3d 864, 873 (Ind. Ct. App. 2020) (Tavitas, J., concurring in result).

499. Id.

500. Id.

501. GARNER ET AL., supra note 352, at 189.

502. Hape v. State, 903 N.E.2d 977, 990 (Ind. Ct. App. 2009).

503. IND. R. EvID. 901(a).

504. Parker v. State, 151 N.E.3d 1269, 1272-73 (Ind. Ct. App. 2020) (citations omitted); accord Brown v. State, 146 N.E.3d 1031, 1036 (Ind. Ct. App.), trans. denied, 150 N.E.3d 1020 (Ind. 2020).

505. Parker, 151 N.E.3d at 1272; Brown, 146 N.E.3d at 1036.

506. See 2017 Survey, supra note 343, at 1077-79; Colin E. Flora, 2018 Developments in Indiana Evidentiary Practice, 52 IND. L. REV. 715, 748-50 (2019) [hereinafter 2018 Survey]; 2019 Survey, supra note 34, at 939-40. 
advancements. ${ }^{507}$ In Parker v. State, the evidentiary challenge was to prove authenticity of Facebook messages sent between a police officer using a fake profile and a Facebook profile purporting to belong to the criminal defendant. ${ }^{508}$ Overruling an authentication challenge to the messages, the trial "court found that the evidence was 'sufficient enough to establish to the Court that there's a reasonable probability that these messages did come from [the Defendant]'s Facebook account,' and overruled the objection." ${ }^{509}$

On review, the court of appeals affirmed admission of the messages by finding guidance in the example of Rule 901(b)(4). ${ }^{510}$ Looking to its own 2014 opinion in Pavlovich v. State, the appellate court observed that Rule 901(b)(4) "often is characterized as authentication solely by circumstantial evidence." 511 Authentication was adequate because the photograph associated with the account was similar to the record on file with the BMV, the profile was under the defendant's name, one of the messages indicated the sender lived on the street that the defendant in fact lived on, the messages arranged a meeting to sell methamphetamine that the defendant showed up for with methamphetamine, and a phone call was placed through the Facebook messenger app from the fake profile to the defendant's profile causing the phone that was in the defendant's possession at the time of his arrest to ring. ${ }^{512}$ "Any lingering doubts about whether [the defendant] wrote the messages went to their evidentiary weight, not their admissibility." ${ }^{513}$ Somewhat surprisingly, the court did not address either M.T.V. v. State or Richardson v. State, which each previously addressed authentication of Facebook messages. ${ }^{514}$

While technology has forced courts to rethink Rule 901, traditional nontechnological challenges still arise, as was seen in Brown v. State. ${ }^{515}$ The issue in

507. Indiana Evidence Rule 901 is patterned on Federal Rule of Evidence 901, which was enacted in 1975. Bone v. State, 771 N.E.2d 710, 716 (Ind. Ct. App. 2002); see United States v. Manos, 848 F.2d 1427, 1431 (7th Cir. 1988); see also United States v. Natale, 526 F.2d 1160, 1173 (2d Cir. 1975), cert. denied, 425 U.S. 950 (1976). Facebook, which was at issue in Parker, was created in 2003-2004. Greenspan v. Random House, Inc., 859 F. Supp. 2d 206, 210 (D. Mass.), aff'd, No. 12-1594, 2012 U.S. App. LEXIS 22285 (1st Cir. 2012).

508. Parker, 151 N.E.3d at 1270-72.

509. Id. at 1272 .

510. IND. R. EVID. 901(b)(4) (“The appearance, contents, substance, internal patterns, or other distinctive characteristics of the item, taken together with all the circumstances.").

511. Parker, 151 N.E.3d at 1273 (quoting Lorraine v. Markel Am. Ins. Co., 241 F.R.D. 534, 546 (D. Md. 2007)) (quotation marks omitted).

512. Id. at 1274 .

513. Id.

514. See 2017 Survey, supra note 343, at 1077-78 (discussing M.T.V. v. State, 66 N.E.3d 960, 963-64 (Ind. Ct. App. 2016), trans. denied, 83 N.E.3d 1220 (Ind. 2017); Richardson v. State, 79 N.E.3d 958, 963-64 (Ind. Ct. App.), trans. denied, 92 N.E.3d 1090 (Ind. 2017)). Both M.T.V. and Richards were addressed in the appellant's brief. See Brief of Appellant at 12, 15-16, Parker, 151 N.E.3d 1269 (No. 20A-CR-315).

515. Brown v. State, 146 N.E.3d 1031, 1036 (Ind. Ct. App.), trans. denied, 150 N.E.3d 1020 
Brown was whether a letter was written by the defendant. ${ }^{516}$ Two other letters had been sent to the court that also purported to be from the defendant, even though the defendant was represented by counsel. ${ }^{517}$ The trial court took judicial notice that the two letters sent to it were from the defendant, creating a rebuttable presumption that the signatures on the letters were from the defendant. ${ }^{518}$ The appellate court found judicial notice appropriate because each letter was sent from the jail where the defendant was being held and the substance of each letter was tailored to the facts of the case and the interests of the defendant - one letter complaining about lack of communication from his court-appointed lawyer and the other requesting the $\mathrm{CCS}$ for the case. ${ }^{519}$ Because the trial court properly took judicial notice, it was incumbent upon the defendant to attempt to rebut the presumption of authenticity. ${ }^{520}$ Although the defendant did present an exhibit attempting to rebut the presumption, it was a matter properly for the jury "to compare the handwriting in the court-filed documents and the writing sample" from the defendant. ${ }^{521}$

In another decision addressing authenticity to traditional forms of evidence, the Indiana Court of Appeals reminded:

The proponent of the business record exhibit may authenticate it by calling a witness who has a functional understanding of the record keeping process of the business with respect to the specific entry, transaction, or declaration contained in the document. The witness must have personal knowledge of the matters set forth in the document. However, [t]he witness need not have personally made or filed the record or have firsthand knowledge of the transaction represented by it in order to sponsor the exhibit. ${ }^{522}$

Because the trial court, in a mortgage-foreclosure action, had rejected documents relating to the underlying loan and mortgage because the witness "was not present at the loan closing, lacked first-hand knowledge of transactions, had not personally made data entries, and was simply reading from documents," the trial court had misapplied the standard, thereby abusing its discretion in excluding the evidence. $^{523}$

(Ind. 2020).

516. Id. at 1034-35.

517. Id.

518. Id. at 1037-38 (discussing Owen v. State, 396 N.E.2d 376, 381 (Ind. 1979)).

519. Id. at 1038 .

520. Id.

521. Id. at 1038 n.3.

522. Wells Fargo Bank, N.A. v. Hallie, 142 N.E.3d 1033, 1038 (Ind. Ct. App. 2020) (alteration in original) (citation and quotation marks omitted).

523. Id. at 1036, 1038-39. 


\section{B. Rule 902: Evidence that is Self-Authenticating}

While Rule 901 requires that evidence be authenticated to be admitted, Rule 902 alleviates the burden to do so for certain categories of evidence that are deemed "self-authenticating[, such that] they require no extrinsic evidence of authenticity in order to be admitted." 524 "Self-authentication does not guarantee admissibility; rather, it relieves the proponent from providing foundational testimony. Evidence will be excluded if the source of information contained in the record or the circumstances of its preparation indicate a lack of trustworthiness." ${ }^{525}$ Two decisions from the survey period addressed Rule 902.

In 487 Broadway Co. v. Robinson, the Indiana Court of Appeals summarily concluded that evidence designated at summary judgment comprised of copies of checks, receipts, warranty deeds, closing settlement statements, and sales disclosure forms were not self-authenticating documents within the ambit of Rule 902. ${ }^{526}$ The court's summary inclusion of "copies of checks" in its list of evidence determined not to be self-authenticating is puzzling. Rule 902(9) deems as selfauthenticating "[c]ommercial paper, a signature on it, and related documents, to the extent allowed by general commercial law." ${ }^{\circ 27}$ As a result, checks have long been viewed as self-authenticating under Rule 902(9). ${ }^{528}$

Wells Fargo Bank, N.A. v. Hallie presented a separate lesson on Rule 902: do not overlook it. ${ }^{529}$ A mortgage-foreclosure action, the trial court excluded documents relating to the underlying mortgage because the plaintiff's witness "was not present at the loan closing, lacked first-hand knowledge of transactions, had not personally made data entries, and was simply reading from documents. ${ }^{~} 530$ In the trial court's esteem, the plaintiff failed to carry its burden to show the proffered documents were authentic. ${ }^{531}$ On interlocutory appeal, the Indiana Court of Appeals reversed and remanded for further proceedings instructing that, on remand, the plaintiff "should be afforded the opportunity to offer exhibits eligible for self-authentication." ${ }^{532}$

524. IND. R. EvID. 902

525. Wells Fargo Bank, 142 N.E.3d at 1038 (citations omitted).

526. 487 Broadway Co., LLC v. Robinson, 147 N.E.3d 347, 353 (Ind. Ct. App. 2020).

527. IND. R. EvID. 902(9).

528. See, e.g., Cardin v. State, 540 N.E.2d 51, 54 n.1 (Ind. Ct. App.), trans. denied (Ind. 1989); United States v. Gray, No. 2:07 CR 166, 2010 U.S. Dist. LEXIS 157187, at*4 (N.D. Ind. Apr. 12, 2010); IHFC Props., LLC v. APA Mktg., Inc., 850 F. Supp. 2d 604, 620 n.10 (M.D.N.C. 2012) (citing United States v. Pang, 362 F.3d 1187, 1192 (9th Cir. 2004); United States v. Hawkins, 905 F.2d 1489, 1494 (11th Cir. 1990)).

529. See Wells Fargo Bank, 142 N.E.3d at 1038.

530. Id. at 1036.

531. Id.

532. Id. at 1038 . 


\section{CONTENTS OF WRITINGS \& RECORDINGS: RULES 1001 THROUGH 1008}

Rule 1002 is often referred to as the "best evidence rule." ${ }^{533}$ The name is a misnomer that invites confusion about its true purpose. ${ }^{534}$ As one court explained:

"The rule is perhaps more accurately dubbed the original document rule, for instead of requiring the 'best' evidence in every case, the rule actually requires the production of an original document rather than a copy." As noted by the [Ninth Circuit]: "Dating back to 1700 , the rule requires not, as its common name implies, the best evidence in every case but rather the production of an original document instead of a copy. Many commentators refer to the rule not as the best evidence rule but as the original document rule." ${ }^{535}$

"Stated differently, under this rule, evidence offered to prove the contents of an original writing, recording, or photograph is not admissible, unless the original itself is also admitted." ${ }^{336}$ Its "purpose . . . is to assure that the trier of the facts has submitted to it the evidence upon any issue that will best enable it to arrive at the truth." 537

Although the rule is centuries old, it has managed to accommodate technological changes. As seen in Caesar v. State, the rule remains a consideration in the age of technology unimagined at the doctrine's inception. ${ }^{538}$ The issue presented was whether the rule was contravened when a police officer was permitted to testify as to the contents of security video that she observed despite the video never being submitted into evidence. ${ }^{539}$ Unfortunately, all that can be taken of note from the opinion is that the best evidence rule "applies to video recordings." 540 The appellate court sidestepped resolving the question of whether there had been error in the admission, determining instead that even were it error, it was harmless. ${ }^{541}$

The survey period also showed a notable development in federal application of Rule 1002 by at least one circuit that differs from the nearly identically worded Indiana Rule 1002. In a split decision, the Tenth Circuit determined, "under the

533. Caesar v. State, 139 N.E.3d 289, 291 (Ind. Ct. App.), trans. denied, 145 N.E.3d 112 (Ind. 2020).

534. Guillermety v. Sec'y of Educ., 341 F. Supp. 2d 682, 689 n.5 (E.D. Mich. 2003). The first sentence of Indiana Evidence Rule 1002 is patterned on Federal Rule of Evidence 1002, meaning that the histories of the two rules are intertwined. As discussed later, that does not, however, mean that there is uniformity in application between Indiana and federal courts. See infra note 542.

535. Id. (citations omitted).

536. United States v. Chavez, 976 F.3d 1178, 1194 (10th Cir. 2020) (emphasis omitted).

537. Caesar, 139 N.E.3d at 291 (quoting Morris v. Crain, 71 N.E.3d 871, 879 (Ind. Ct. App. 2017)) (quotation marks omitted).

538. Id. at 290-92.

539. Id. at 290.

540. Id. at 291 .

541. Id. at 292. 
plain meaning of Rule 1002, the best-evidence rule does not permit courts to admit English-translation transcripts of foreign-language recordings when the recordings themselves are not also in evidence." ${ }^{542}$ Dissenting jurist Harris L. Hartz would have ruled otherwise by following the guidance of the Indiana Supreme Court's 2011 opinion in Romo v. State, ${ }^{543}$ which "h[e]ld that English language translation transcripts of statements recorded in a foreign language, if otherwise admissible, may properly be considered as substantive evidence." ${ }^{\prime 54}$ Notably, the Romo decision was guided by opinions from the Fifth, Seventh, and Eighth Circuits, ${ }^{545}$ so Indiana's approach has not been fully eschewed by federal courts.

\section{COMMON LAW RULES: \\ CORPUS DELICTI, RES IPSA LOQUITUR, PAROL EVIDENCE, \& SPOLIATION}

"While the Rules of Evidence generally superceded [sic] previously existing common law," 546 if the Indiana Rules of Evidence "do not cover a specific evidence issue, common or statutory law shall apply." "547 And, as one federal jurist recently observed, neither the party seeking to wholly abandon a common-law evidentiary practice nor the court could "locate[] a single instance where an Indiana court has held that long-standing common law precedents were irrelevant merely because an Indiana Rule of Evidence now governs the legal question when the Rule at issue did not explicitly undermine those precedents." 548 Yet again, ${ }^{549}$ the survey period reminded that many common-law evidentiary doctrines remain alive and well in Indiana practice.

\section{A. Corpus Delicti Rule}

Common law has "established ... that the state cannot prove the commission of a crime by the extra-judicial confession alone of a defendant." ${ }^{250}$ The rationale for this corpus delicti rule is to protect "the generally accepted principles of the

542. United States v. Chavez, 976 F.3d 1178, 1195 (10th Cir. 2020) (emphasis omitted).

543. Id. at 1223 (Hartz, J., dissenting) (citing Romo v. State, 941 N.E.2d 504, 508 (Ind. 2011)).

544. Romo, 941 N.E.2d at 508.

545. Id. at 507-08 (citing United States v. Onori, 535 F.2d 938 (5th Cir. 1976)); United States v. Valencia, 957 F.2d 1189, 1194 (5th Cir. 1992), overruled on other grounds by United States v. Keith, 230 F.3d 784 (5th Cir. 2000); United States v. Estrada, 256 F.3d 466 (7th Cir. 2001); United States v. Grajales-Montoya, 117 F.3d 356, 367 (8th Cir. 1997); United States v. Placensia, 352 F.3d 1157, 1165 (8th Cir. 2003)).

546. Specht v. State, 734 N.E.2d 239, 240 (Ind. 2000).

547. IND. EvID. R. 101(b).

548. Myers v. Superintendent, 410 F. Supp. 3d 958, 1003 (S.D. Ind. 2019), rev'd and remanded for further consideration sub nom. Myers v. Neal, 975 F.3d 611 (7th Cir. 2020).

549. See 2017 Survey, supra note 343, at 1080-82; 2018 Survey, supra note 506, at 752-58; 2019 Survey, supra note 34, at 943-51.

550. Hogan v. State, 132 N.E.2d 908, 910 (Ind. 1956). 
common law, that one may not be induced to convict himself." ${ }^{551}$ It also serves "to prevent the admission of a confession to a crime which never occurred." 552 Thus, in order to sustain a criminal conviction, a confession of guilt must be accompanied by "independent proof of the corpus delicti." ${ }^{553}$ The independent evidence must be sufficient to "provide an inference that the crime charged was [actually] committed." ${ }^{, 54}$ Circumstantial evidence may be sufficient to satisfy the rule. ${ }^{55}$

There are two aspects to the corpus delicti rule. The rule comes into play both in determining whether the evidence is sufficient to sustain a conviction and, separately, whether the evidence is sufficient to admit a pre-trial confession. ${ }^{556}$ "[I]n order to sustain a conviction, the corpus delicti must be proved beyond a reasonable doubt." ${ }^{557}$ But, in order to admit a confession into evidence, Indiana courts only "require[] independent evidence of (1) the occurrence of the specific kind of injury . . . and (2) somebody's criminal act as the cause of the injury." "558 The showing to admit a confession into evidence need not be made "prior to the admission of a confession, provided the totality of independent evidence presented at trial establishes the corpus delicti." ${ }^{559}$

Two decisions from the Indiana Court of Appeals, J.C. v. State ${ }^{560}$ and Johnson v. State, ${ }^{561}$ addressed the propriety of admitting extra-judicial confessions in light of the corpus delicti rule. In J.C., the court found ample independent evidence to support adjudication as a delinquent child for what would constitute child molestation on an infant where a witness testified to seeing the delinquent child

jump[] up "real fast ... like [he] was caught" ... [and] buckle his pants quickly while his back was to [the witness,] . . . [and] noticed that the front strap of [the infant's] diaper was above her belly button and her diaper was rolled up and tucked up underneath her vagina, exposing her entire genital area. ${ }^{562}$

551. Id.

552. J.C. v. State, 140 N.E.3d 865, 868 (Ind. Ct. App. 2019) (citation omitted).

553. Johnson v. State, 150 N.E.3d 647, 652 (Ind. Ct. App. 2020) (quoting Shinnock v. State, 76 N.E.3d 841, 843 (Ind. 2017)); accord J.C., 140 N.E.3d at 868.

554. Johnson, 150 N.E.3d at 652 (quoting Shinnock, 76 N.E.3d at 843); accord J.C., 140 N.E.3d at 868.

555. Johnson, 150 N.E.3d at 652; J.C., 140 N.E.3d at 868; Stocking v. State, 7 Ind. 326, 32931 (1855).

556. Johnson, 150 N.E.3d at 652.

557. Shinnock, 76 N.E.3d at 844 (citation omitted).

558. Johnson, 150 N.E.3d at 652 (quoting Cambron v. State, 322 N.E.2d 712, 715 (Ind. 1975)) (ellipses in original).

559. J.C., 140 N.E.3d at 868-69 (emphasis omitted).

560. Id. at 865 .

561. Johnson, 150 N.E.3d 647.

562. J.C., 140 N.E.3d at 869 . It is asserted that there was also video evidence but that it was 
While J.C. posed an easy resolution for the appellate court, Johnson was a much more difficult matter. ${ }^{53}$ The defendant appealed a conviction for battering an on-again-off-again girlfriend using a "security stick." ${ }^{564}$ During an interview with the alleged victim, she advised a detective that the defendant "had battered her one week prior to [a later] fire." ${ }^{565}$ As part of the investigation, the detective photographed injuries to the alleged victim "and took a security stick from [her] apartment. ${ }^{1566}$ The alleged victim, however, did not testify at trial. ${ }^{567}$ The absence of her testimony proved dispositive to the state establishing a basis to admit the defendant's confession to the charged offense. ${ }^{568}$ Without the alleged victim's testimony, "there [was] no evidence that connects [the defendant] to ownership or use of the security stick." ${ }^{569}$ Nor was there evidence that connected the defendant to the alleged victim's injuries, because the alleged victim's statement to the detective "was not admitted as substantive evidence." ${ }^{170}$ The photographs of the injuries, the security stick, and the detective's testimony "that she was investigating an unreported battery and prepared a police report regarding domestic battery and strangulation as a result of her interview with" the alleged victim were insufficient to meet the corpus delicti rule as a basis for admitting the confession into evidence. ${ }^{571}$

\section{B. Res Ipsa Loquitur}

Under Indiana law, res ipsa loquitur is an evidentiary doctrine that permits an inference of negligence to be drawn from certain key facts: (1) the instrumentality of the plaintiff's injury was within the exclusive management and control of the defendant, and (2) the accident was of the type that ordinarily would not happen if those who have management and control exercise due care. ${ }^{572}$

The last survey addressed the opinion in Till v. Dolgencorp, LLC from the United States District Court for the Southern District of Indiana. ${ }^{573}$ This survey

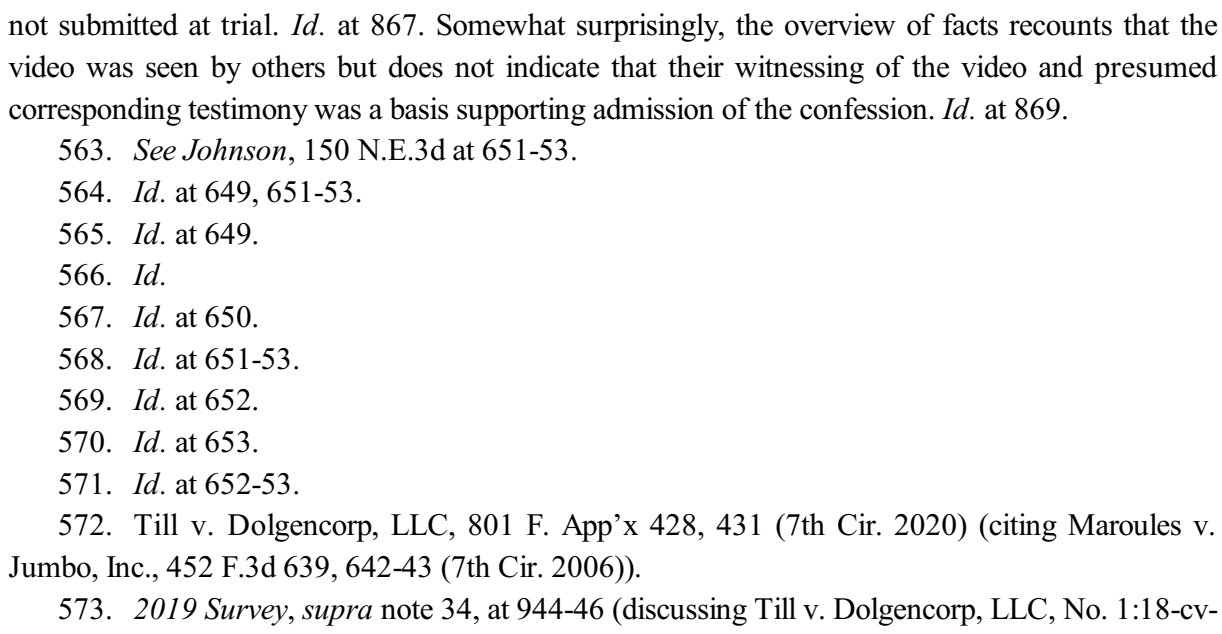


period produced the Seventh Circuit's ruling reviewing the district court's grant of summary judgment. ${ }^{574}$ At issue was whether the doctrine applied in the setting of a delivery-truck driver injured while unloading merchandise from the truck that was packaged by the defendant into "roll-tainers," alleged to have been improperly loaded to be top heavy, ultimately causing the driver to lose control of the roll-tainer and suffering severe injuries as a result. ${ }^{576}$ The district court rejected invocation of res ipsa loquitur because the defendant had "relinquished all control over the trailer and roll-tainers" prior to the driver's injuries. ${ }^{577}$ "Thus," the district court concluded, "it could not be said that [the defendant] exercised exclusive control over the instrumentality of [the driver]'s injury (i.e., the top-heavy roll-tainer) as would be required to prevail under a res ipsa loquitur injury." ${ }^{178}$ The Seventh Circuit, though affirming the district court, did not land on the same basis for rejecting the res ipsa loquitur theory-id est lack of control. Instead, the Seventh Circuit's basis for upholding summary judgment had little to do with the doctrine. ${ }^{579}$

The inference provided by successful invocation of the doctrine, however, does not supplant the obligation to first establish the existence of a duty of care. ${ }^{580}$ "So unless [the defendant] owed [the driver] a duty of care under Indiana law, it $\mathrm{d}[\mathrm{id}]$ not matter whether or not [the defendant] was negligent in packing the rolltainer." ${ }^{581}$ The appellate court determined that the plaintiff neither raised duty arguments before the trial court sufficient to preserve the issue for appeal, nor were arguments relating to res ipsa loquitur "so "logically intertwined" that plaintiff "may be said to have developed and preserved an argument as to duty as well." ${ }^{582}$ Finding no duty, the Seventh Circuit affirmed summary judgment. ${ }^{583}$

The Southern District of Indiana provided the only other notable decision on the doctrine, falling within the survey period. One of the most common circumstances for invoking the doctrine is as a means to circumvent the general requirement for expert medical testimony in medical-malpractice cases. ${ }^{584}$ That

00127-TWP-DLP, 2019 U.S. Dist. LEXIS 117715, at *10-16 (S.D. Ind. July 16, 2019), aff'd, 801

F. App'x, 428).

574. Till, 801 F. App'x at 428.

575. "A roll-tainer is a cart used to deliver Dollar General goods. It is a steel cage on three sides, and the fourth side has a net with a steel bar to lock it in." Till, 2019 U.S. Dist. LEXIS 117715 , at $* 2-3$ (record citation omitted).

576. Till, 801 F. App'x at 430.

577. Id. at 431 .

578. Id.

579. See id. at 432 .

580. Id.

581. Id.

582. Id.

583. Id. at 432-33.

584. See Chi Yun Ho v. Frye, 880 N.E.2d 1192, 1201 (Ind. 2008) ("Unless satisfied by the rule of res ipsa loquitur, a medical malpractice plaintiff is ordinarily required to present expert opinion that a defendant health care provider's conduct fell below the applicable standard of care.”). 
was precisely why the doctrine was invoked in Solis $v$. United States. ${ }^{585}$ In order to prosecute a medical-malpractice action, "[e]xpert testimony is required unless ... the defendant's conduct is 'understandable without extensive technical input' or 'so obviously substandard that one need not possess medical expertise to recognize the breach." ${ }^{586}$ Alternatively, a plaintiff may also be able to invoke the doctrine of res ipsa loquitur to relieve him of the need to advance expert testimony ${ }^{587}$ In Solis, the doctrine proved no salvation. Without delving into an explicit analysis of the doctrine, the court easily found expert testimony necessary to prove negligence in the provision of medical care "for the five different bacteria found to be growing in [the plaintiff]'s throat." 588

\section{Parol \& Extrinsic Evidence Rule}

"Indiana's parol evidence rule will often prevent a party from introducing evidence outside the documents - such as evidence of representations made during negotiations." ${ }^{589}$ The parol evidence rule dictates that "extrinsic evidence is not admissible to add to, vary or explain the terms of a written instrument if the terms of the instrument are susceptible of a clear and unambiguous construction." 590 "A document is not ambiguous merely because parties disagree about a term's meaning. Rather, language is ambiguous only if reasonable people could come to different conclusions as to its meaning." 591 The rule can summarily terminate a third-party beneficiary claim where the unambiguous contract evinces no evidence that a person outside the contract was intended to derive a protectable

585. Solis v. United States, No. 2:18-cv-00292-JPH-DLP, 2020 U.S. Dist. LEXIS 95369, at *8-11 (S.D. Ind. June 1, 2020).

586. Id. at *9 (quoting Gipson v. United States, 631 F.3d 448, 451 (7th Cir. 2011)).

587. Id.

588. Id. at $* 10$.

589. Pac. Controls, Inc. v. Cummins Inc., No. 19-cv-03428 (CM), 2019 U.S. Dist. LEXIS 215423, at*17 (S.D.N.Y. Dec. 13, 2019) (citation omitted).

590. Acheron Med. Supply, LLC v. Cook Med. Inc., 958 F.3d 637, 643 (7th Cir. 2020) (quoting Roberts v. Cmty. Hosps. of Ind., Inc., 897 N.E.2d 458, 467 (Ind. 2008)). Although the cited authority speaks of the "four corners rule," Indiana caselaw typically treats the parol evidence rule, extrinsic evidence rule, and four corners rule as synonyms. See, e.g., Pepka v. Branch, 294 N.E.2d 141, 154 (Ind. Ct. App. 1973) (referring to the rules as a single "parol and extrinsic evidence rule"); $c f$. Patton v. Mid-Continent Sys., Inc., 841 F.2d 742, 745 (7th Cir. 1988) ('Granted, the 'four corners,' 'extrinsic evidence,' and parol evidence rules are often run together, as in American Fletcher National Bank \& Trust Co. v. Pavilion, Inc., 434 N.E.2d 896, 904 (Ind. App. 1982), vacated on other grounds, 453 N.E.2d 156 (Ind. 1983). The first two rules seem identical; and Hauck v. Second National Bank of Richmond, 153 Ind. App. 245, 260, 286 N.E.2d 852,861 (1972), describes the parol evidence rule as a 'logical extension' of the 'four corners' rule.").

591. Candy Penrod v. Quality Corr. Care LLC, No. 2:18 CV 219, 2020 U.S. Dist. LEXIS 18923 , at $* 8$ (N.D. Ind. Feb. 5, 2020) (quoting Univ. of S. Ind. Found. v. Baker, 843 N.E.2d 528, 532 (Ind. 2006)). 
benefit $t^{52}$ and prohibit an insurer from "offer[ing] extrinsic evidence to prove the meaning of policy terms." ${ }^{593}$ Federal courts, applying Indiana law, also recognized two important circumstances when the rule does not apply: "contracts that are partly written and partly oral" 594 and where a party to the contract was "fraudulently induced to enter into" the contract because "fraud arising out of the negotiations leading up to the execution of a written contract is not merged therein." $" 595$

\section{Spoliation}

"Under Indiana law, a party may not lose, destroy or suppress material facts or evidence prior to the commencement of the lawsuit that the party knew or should have known was imminent." ${ }^{596}$ A party that fails to produce or preserve documents when it has a duty to do so, commits spoliation and is subject to a wide variety of sanctions to be implemented at the trial court's discretion. ${ }^{597}$ Viewed by many as a "discovery abuse," 598 "[s]poliation is treated generally, but by no means exclusively, as an evidentiary issue." 599 Accordingly, although sanctions may include default judgment ${ }^{600}$ most often the sanction for spoliation will manifest as an adverse inference at trial ${ }^{601}$ or summary judgment. ${ }^{602}$ Spoliation may also be pursued as an independent cause of action and, when

592. Id. at $* 9$.

593. In re USA Gymnastics, Nos. 18-9108-RLM-11, 19-50012, 2019 Bankr. LEXIS 3972, at *49 (Bankr. S.D. Ind. 2019).

594. R3 Composites Corp. v. G\&S Sales Corp., 960 F.3d 935, 947 (7th Cir. 2020) (Sykes, J., dissenting).

595. Pac. Controls, 2019 U.S. Dist. LEXIS 215423, at *17-18 (quoting Jones v. Oakland City Univ., 122 N.E.3d 911, 921 (Ind. Ct. App.), trans. denied, 134 N.E.3d 1013 (Ind. 2019)).

596. Aspen Am. Ins. Co. v. Interstate Warehousing, Inc., No. 1:14-CV-383, 2019 U.S. Dist. LEXIS 209810, at*7 (N.D. Ind. Dec. 5, 2019) (quoting ArcelorMittal Ind. Harbor LLC v. Amex Nooter, LLC, No. 2:15-CV-195-PRC, 2018 U.S. Dist. LEXIS 10141, at *3 (N.D. Ind. Jan. 23, 2018)) (quotation marks omitted).

597. Carmichael v. Separators, Inc., 148 N.E.3d 1048, 1060 (Ind. Ct. App.), trans. denied, 157 N.E.3d 521 (Ind. 2020); N. Ind. Pub. Serv. Co. v. Aqua Envtl. Container Corp., 102 N.E.3d 290, 301 (Ind. Ct. App. 2018) ("A party raising a claim of spoliation must prove that (1) there was a duty to preserve the evidence, and (2) the alleged spoliator either negligently or intentionally destroyed, mutilated, altered, or concealed the evidence." (citation omitted)); $c f$. Glotzbach v. Froman, 854 N.E.2d 337, 339 (Ind. 2006) (finding "no common law duty on the part of an employer to preserve, for an employee, potential evidence in an employee's possible third party action" following workplace injury (citation omitted)).

598. Aspen Am. Ins., 2019 U.S. Dist. LEXIS 209810, at *5 (citation omitted).

599. Douglas E. Cressler, Spoliation of Evidence, 36 RES GeStæ 510 (1993).

600. See, e.g., Carmichael, 148 N.E.3d at 1060-65.

601. See, e.g., Aspen Am. Ins., 2019 U.S. Dist. LEXIS 209810, at*5-30.

602. See, e.g., Porter v. Irvin's Interstate Brick \& Block Co., 691 N.E.2d 1363, 1365 (Ind. Ct. App. 1998) (permitting inference arising from spoliation to resist summary judgment). 
occurring in the provision of medical services, can be subject to the procedures of Indiana's Medical Malpractice Act. ${ }^{603}$

"A party raising a claim of spoliation must prove that (1) there was a duty to preserve the evidence, and (2) the alleged spoliator either negligently or intentionally destroyed, mutilated, [al]tered, or concealed the evidence."604

Determining whether sanctions are warranted and, if so, what they should include, requires a court to consider both the spoliating party's culpability and the level of prejudice to the party seeking discovery. Culpability can range along a continuum from destruction intended to make evidence unavailable in litigation to inadvertent loss of information for reasons unrelated to the litigation. Prejudice can range along a continuum from an inability to prove claims or defenses to little or no impact on the presentation of proof. A court's response to the loss of evidence depends on both the degree of culpability and the extent of prejudice. Even if there is intentional destruction of potentially relevant evidence, if there is no prejudice to the opposing party, that influences the sanctions consequence. And even if there is an inadvertent loss of evidence but severe prejudice to the opposing party, that too will influence the appropriate response, recognizing that sanctions (as opposed to other remedial steps) require some degree of culpability ${ }^{605}$

Finding the highest degree of culpability possible, the Indiana Court of Appeals, in Carmichael v. Separators, Inc., affirmed the entry of default judgment as a proper sanction for the intentional destruction and concealment of evidence ${ }^{606}$ Finding a low degree of culpability but a non-negligible degree of prejudice, the Northern District of Indiana dictated, as a remedy for spoliation, that the jury would be instructed that it "may, but is not required to, conclude that evidence that might have been obtained from an inspection of the warehouse components removed from the site would have been unfavorable to" the defendant. ${ }^{607}$ And, the Southern District of Indiana, finding neither intentionality nor negligence in the failure of a store to preserve video evidence of a customer's fall that resulted in injury, declined to issue any spoliation sanctions against the store. ${ }^{608}$

603. Cortez v. Ind. Univ. Health Inc., 151 N.E.3d 332, 341-43 (Ind. Ct. App. 2020).

604. Whitlock v. Menard, Inc., No. 1:18-cv-01386-TWP-TAB, 2020 U.S. Dist. LEXIS 1277, at *22 (S.D. Ind. 2020) (citation omitted).

605. Carmichael, 148 N.E.3d at 1060-61 (quoting Howard Reg'1 Health Sys. v. Gordon, 952 N.E.2d 182, 189-90 (Ind. 2011)).

606. Id. at 1070-71.

607. Aspen Am. Ins. Co. v. Interstate Warehousing, Inc., No. 1:14-CV-383, 2019 U.S. Dist. LEXIS 209810, at *30 (N.D. Ind. Dec. 5, 2019).

608. Whitlock, 2020 U.S. Dist. LEXIS 1277, at*21-25. 


\section{STATUTORY EVIDENTIARY PROCEDURES - Protected PERSON STATUTE}

Like common-law procedures, Indiana statutory procedures were not abrogated by the adoption of the Indiana Rules of Evidence unless specifically contradicted by a rule. ${ }^{609}$ One statutory procedure not in conflict with the rules of evidence is Indiana's Protected Person Statute. ${ }^{610}$ The statute "allows a statement or videotape of a protected person as admissible evidence in a criminal proceeding if certain conditions are met." ${ }^{\prime 11}$ The statute applies to all persons under the age of fourteen years and, in certain instances of diminished capacity, persons older than fourteen who have been a victim of specifically delineated crimes. ${ }^{612}$ While the statute permits use of recorded statements made prior to trial by a protected person, it does not permit fully unfettered use of such recordings at trial. ${ }^{613}$ In Reynolds v. State, the Indiana Court of Appeals determined that it was error to both allow the live testimony of a protected person and a video of a forensic interview of the protected person, though concluded such error was not a basis for reversal in that case. ${ }^{614}$

\section{CONCLUSION}

Even a period largely shaped by a global pandemic, ${ }^{615}$ reminds that Indiana evidentiary practice, though now carved into formal rules of practice, remains an ever-developing area of the law.

609. IND. EvID. R. 101(b); see also IND. CoDE § 34-8-1-3 (2021); Brim v. State, 624 N.E.2d 27, 33 (Ind. Ct. App. 1993), trans. denied (Ind. 1994) (“[W]hen a statute purports to establish a rule of evidence which conflicts with a common law rule of evidence established by the Indiana Supreme Court, the supreme court rule prevails and the statute is a nullity.").

610. IND. CoDE § 35-37-4-6; see also Tyler v. State, 903 N.E.2d 463, 467 (Ind. 2009) (The Protected Person Statute is "a part of Indiana evidence law, though not in the Rules.”).

611. Crabtree v. State, 152 N.E.3d 687, 694 n.5 (Ind. Ct. App.), trans. denied, 160 N.E.3d 515 (Ind. 2020).

612. IND. CODE $\S 35-37-4-6$. The age of the victim is assessed at the time of trial. Id. § 35-374-6(d)(1); see also Hayes v. State, 474 P.3d 1179, 1184 n.7 (Alaska Ct. App. 2020).

613. See, e.g., Tyler, 903 N.E.2d at 465-67.

614. Reynolds v. State, 142 N.E.3d 928, 939-42 (Ind. Ct. App.), trans. denied, 149 N.E.3d 597 (Ind. 2020).

615. See Mays v. Dart, 974 F.3d 810, 814 (7th Cir. 2020) (“At present, COVID-19 requires no introduction: the novel coronavirus causing this disease has spread around the world, resulting in an unprecedented global pandemic that has disrupted every aspect of public life."). 